\title{
Circulation and Deep-Water Export at the Western Exit of the Subpolar North Atlantic
}

\author{
Friedrich A. Schott, Rainer Zantopp, Lothar Stramma, Marcus Dengler, Jürgen Fischer, And \\ Mathieu Wibaux* \\ Institut für Meereskunde, Kiel, Germany
}

(Manuscript received 25 April 2003, in final form 27 October 2003)

\section{ABSTRACT}

\begin{abstract}
The current system east of the Grand Banks was intensely observed by World Ocean Circulation Experiment (WOCE) array ACM-6 during 1993-95 with eight moorings, reaching about $500 \mathrm{~km}$ out from the shelf edge and covering the water column from about 400-m depth to the bottom. More recently, a reduced array by the Institut für Meerskunde (IfM) at Kiel, Germany, of four moorings was deployed during 1999-2001, focusing on the deep-water flow near the western continental slope. Both sets of moored time series, each about 22 months long, are combined here for a mean current boundary section, and both arrays are analyzed for the variability of currents and transports. A mean hydrographic section is derived from seven ship surveys and is used for geostrophic upper-layer extrapolation and isopycnal subdivision of the mean transports into deep-water classes. The offshore part of the combined section is dominated by the deep-reaching North Atlantic Current (NAC) with currents still at $10 \mathrm{~cm} \mathrm{~s}^{-1}$ near the bottom and a total northward transport of about $140 \mathrm{~Sv}\left(\mathrm{~Sv} \equiv 10^{6} \mathrm{~m}^{3}\right.$ $\mathrm{s}^{-1}$ ), with the details depending on the method of surface extrapolation used. The mean flow along the western boundary was southward with the section-mean North Atlantic Deep Water outflow determined to be 12 Sv below the $\sigma_{\theta}=27.74 \mathrm{~kg} \mathrm{~m}^{-3}$ isopycnal. However, east of the deep western boundary current (DWBC), the deep NAC carries a transport of $51 \mathrm{~Sv}$ northward below $\sigma_{\theta}=27.74 \mathrm{~kg} \mathrm{~m}^{-3}$, resulting in a large net northward flow in the western part of the basin. From watermass signatures it is concluded that the deep NAC is not a direct recirculation of DWBC water masses. Transport time series for the DWBC variability are derived for both arrays. The variance is concentrated in the period range from $\sim 2$ weeks to 2 months, but there are also variations at interannual and longer periods, with much of the DWBC variability being related to fluctuations and meandering of the NAC. A significant annual cycle is not recognizable in the combined current and transport time series of both arrays. The moored array results are compared with other evidence on deep outflow and recirculation, including recent models of different types and complexity.
\end{abstract}

\section{Introduction}

The western North Atlantic off the Grand Banks has attracted considerable attention over the past decades, and observations have shown very complex circulation patterns. Directly offshore cold waters from the Labrador Sea, with near-surface temperatures of less than about $7^{\circ} \mathrm{C}$ even in summer, flow southward after having passed either through Flemish Pass with a sill depth of $1100 \mathrm{~m}$ (Petrie and Buckley 1996) or around Flemish Cap (Figs. 1 and 2). Farther offshore and typically separated by a sharp front, much warmer subtropical waters with near-surface temperatures of more than $18^{\circ} \mathrm{C}$ in summer flow northward in the North Atlantic Current (NAC).

* Visiting from Ecole Centrale, Nantes, France.

Corresponding author address: Dr. Friedrich A. Schott, Institut für Meereskunde, FB - 1 Physikalische Ozeanographie, Düsternbrooker Weg 20, D-24105 Kiel, Germany.

E-mail: fschott@ifm.uni-kiel.de
A well-known and permanent feature of the NAC pathway is the "Northwest Corner," its most northwestern excursion into the Labrador Sea at about $51^{\circ} \mathrm{N}$ (Fig. 1; e.g., Fratantoni 2001). After having passed the Northwest Corner, the NAC continues toward the Gibbs Fracture Zone in a latitudinally varying band before splitting up farther in the eastern basin (Krauss 1986; Rossby 1996; Reverdin et al. 2003). Beginning with Mann (1967) and Worthington (1976), large, apparently permanent, recirculation cells in the Newfoundland Basin were proposed. The "Mann Eddy" is a presumed anticyclonic cell with its center near $42^{\circ} \mathrm{N}, 44^{\circ} \mathrm{W}$, sketched into Fig. 1. Rossby (1996) and Käse and Krauss (1996), evaluating drifters and acoustically tracked floats, then proposed a meandering path of the NAC around several cyclonic and anticyclonic recirculation cells east of the Grand Banks. Recent analysis of the increased drifter database has confirmed the existence of narrow near-zonal currents east of the Grand Banks at about $43^{\circ}$ and $47^{\circ} \mathrm{N}$ (Reverdin et al. 2003). Schmitz and McCartney (1993), expanding on earlier 


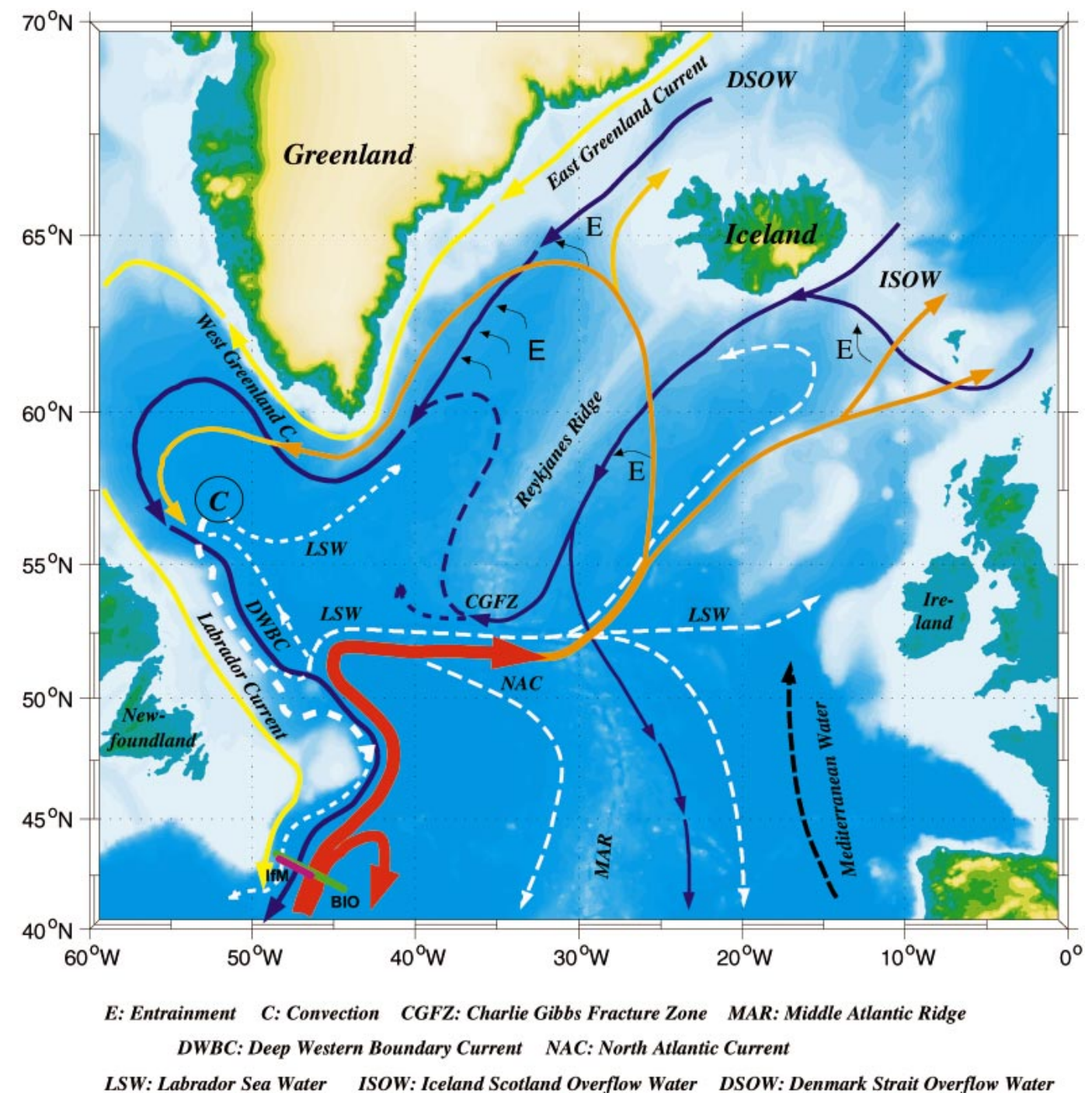

FIG. 1. Schematic circulation diagram of the subpolar North Atlantic with the different current branches identified. Moored array location marked by heavy bar in lower left (green, BIO; magenta, IfM).

analyses of Worthington (1976), evaluated the then-existing hydrographic database for an overall schematic diagram of the meridional overturning and deep-water circulation. They estimated the deep western boundary current (DWBC) export to be $17 \mathrm{~Sv}\left(\mathrm{~Sv} \equiv 10^{6} \mathrm{~m}^{3} \mathrm{~s}^{-1}\right)$ and concluded on the existence of an anticyclonic recirculation cell of more than $30 \mathrm{~Sv}$ for the waters colder than $7^{\circ} \mathrm{C}$ east of the DWBC in the Newfoundland Basin. In the past decade, a number of new studies have been carried out east of the Grand Banks within the context of the World Ocean Circulation Experiment (WOCE) and new results on the overturning circulation are steadily becoming available. One of the crucial Atlantic WOCE sections was the line A2, running from the Grand Banks over to Europe (Koltermann et al. 1999). A meridional overturning circulation (MOC) transport of $14 \mathrm{~Sv}$ across that " $48^{\circ} \mathrm{N}$ line" (although located near $43^{\circ} \mathrm{N}$ east of the Grand Banks) was obtained in the global inverse model studies of Ganachaud and Wunsch (2000) and Lumpkin and Speer (2003). Lumpkin and Speer (2003) also found that the anticyclonic deep gyre proposed by Schmitz and McCartney (1993) was no longer present when an objectively determined reference level was applied.

An extensive experiment with a moored current-meter array consisting of eight stations was carried out by the Bedford Institute of Oceanography (BIO) from August 1993 to July 1995 along the western end of the A2 line (Clarke et al. 1998). They determined a transport time series using objective mapping for the cross section below $400 \mathrm{~m}$ (covered by the instruments) and surface extrapolation based on geostrophic shears for the upper layer. Adding up all of the northward contributions, they obtained a mean northward transport of $140 \mathrm{~Sv}$ while 


\section{Grand Banks Moored Arrays}

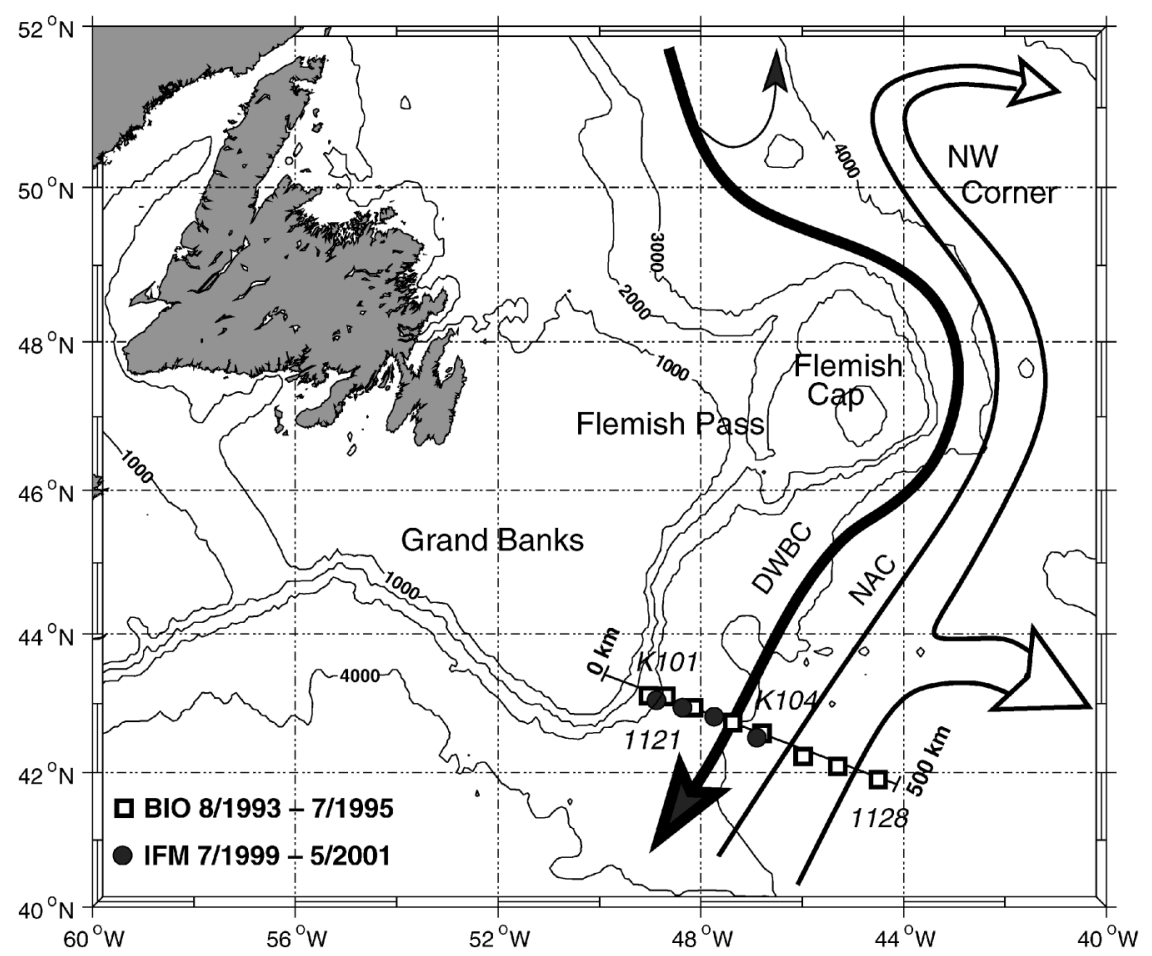

FIG. 2. Bathymetry of the Grand Banks region with schematic circulation branches and locations of the BIO array of 1993-95 (moorings 1121-1128) and of the IfM Kiel array of 1999-2001 (moorings K101-K104).

the integral of all southward contributions yielded a total of 25 Sv. Clarke et al. (1998) suggested that the high northward transport was due to partial inclusion of the western part of the Mann Eddy into the transport integral. The array was complemented by inverted echosounders (IESs). Combining the IES travel time inversions with the moored array temperatures and bottom current and pressure measurements, Meinen and Watts (2000) and Meinen (2001) created a mean current section for which they derived a mean transport of the NAC and the inshore part of the Mann Eddy of $146 \pm 13 \mathrm{~Sv}$.

In summer of 1999 a new moored array was deployed along the western end of the WOCE A2 line within the context of the special research program, or "Sonderforschungsbereich" (SFB 460, Dynamics of Thermohaline Circulation Variability) conducted by the Institut für Meerskunde (IfM) at Kiel, Germany. Central objectives of the SFB 460 are the study of the formation of the Labrador Sea Water (LSW) through deep convection and its interannual variability as well as water mass transformations related to the overflows and the potential relations of these processes to the variability of the Atlantic thermohaline circulation (THC) and associated heat transport. Since the beginning of the SFB 460 field work in 1996, moored array observations have been carried out continuously in the boundary currents of the Labrador Sea (Fischer et al. 2004, hereinafter FSD), and
CTD surveys have been repeated each year in summer (Rhein et al. 2002; Stramma et al. 2004, manuscript submitted to Deep-Sea Res., hereinafter SDSR). In addition, watermass pathways were studied using profiling floats of the profiling autonomous Lagrangian circulation explorer (PALACE) type (Fischer and Schott 2002). The IfM Kiel array from 1999 to 2001 east of the Grand Banks was only instrumented to measure the cold water outflow along the western boundary and therefore only covered the innermost part of the previous BIO array.

The structure of this paper is as follows. After presenting selected time series of the current fluctuations from the BIO and IfM arrays and discussing the analysis methods used, we will construct, as a first main result, a mean-current cross section. It is based on the moored measurements from both arrays augmented by the geostrophic shears from a mean shipboard section. We will then derive transport time series from both arrays, focusing on the deep-water flow along the boundary. Water mass signatures from the ship surveys will be used to investigate whether the southward boundary flow can be identified as a deep-water export or whether there is a possibility that much of it recirculates northward within the interior of the basin. Last, the transports from the two deployments separated by six years will be compared with other observational and modeling evidence 


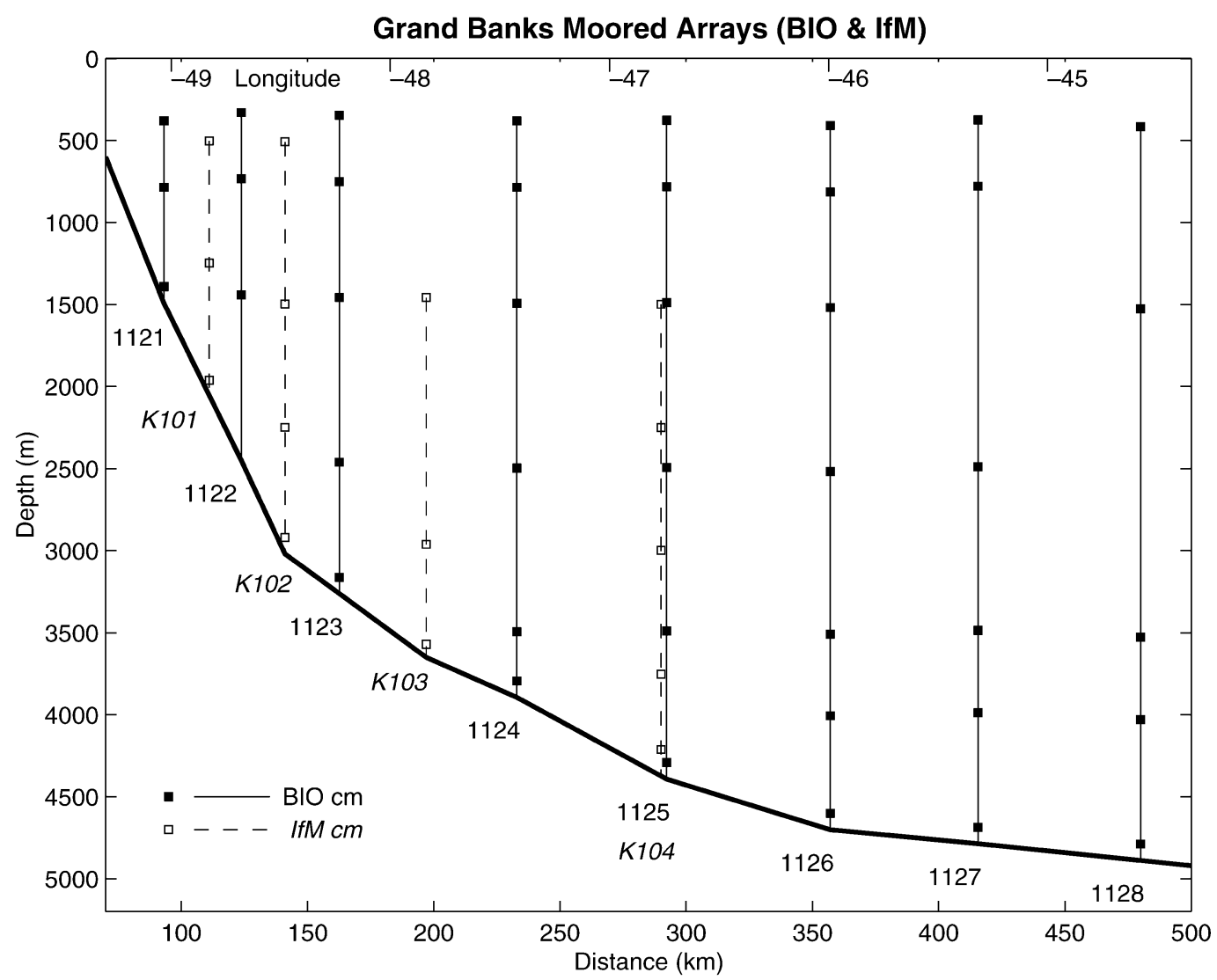

FIG. 3. Current-meter distributions of BIO moorings 1121-1128 and IfM Kiel moorings K101-K104.

of deep-water export from the subpolar basin and interior recirculation.

\section{The observations and analysis}

\section{a. The 1993-95 moored array}

The BIO array, identified by WOCE as ACM-6, consisted of eight moorings, 1121-1128, with 41 Aanderaa rotor current meter records available from the WOCE archives and covered the continental slope from a water depth of 1500 to $4800 \mathrm{~m}$ (Figs. 2 and 3). The westernmost mooring, 1121, delivered only short records at the upper two levels (because of instrument failures; see Table 1), and the top instrument of 1124 also failed to record current measurements, leaving a total of 38 more or less complete records for our transport time series analysis. The data have been 3-day low passed and subsampled daily to eliminate tides and other high frequency variability not of interest in this analysis. The vectors have been rotated such that southwestward, toward $203^{\circ} \mathrm{T}$, along the topography is downward in the plots. The upper-level currents, presented here for the depth level of approximately $800 \mathrm{~m}$ (Fig. 4a: at 1128 that level was not occupied and the $1526-\mathrm{m}$ record is shown instead), are much stronger for the offshore moorings (1125-1128) than the onshore moorings be- cause of the presence of the NAC. The strong offshore variability is largely correlated among moorings 11251128 at their upper levels and this correlation extends to the bottom meters (Fig. 4b), particularly on moorings 1126 and 1127. A more formal discussion of correlations follows in section 4.

The near-bottom current meters exhibit a different pattern (Fig. 4b). The inshore moorings (1121-1125) are dominated by southward flow, while the deep records of stations 1126 and 1127 are dominated by northward flow. At mooring 1128, the farthest offshore, there is a noticeable change in the offshore flow regime, beginning with a weakening of the northward flow by late 1994, followed by a period of intense near-barotropic southeastward flow in March 1995 after a year of almost no southward flow at all.

The individual instruments were undergoing considerable tilting and vertical displacements due to the large current fluctuations. Therefore, current profiles were reassembled for the individual stations using the instantaneous depths as derived from the pressure sensors available from some of the instruments. Then the profiles were interpolated vertically for each of the moorings and the resulting currents reassigned to fixed depths, including shear extrapolation to the surface. This also eliminated data gaps from some instruments within 
TABLE 1. Moorings used in the present analysis (ID is identification number).

\begin{tabular}{|c|c|c|c|c|c|c|c|}
\hline ID & $\begin{array}{l}\text { Lat, lon, } \\
\text { bottom depth }\end{array}$ & $\begin{array}{l}\text { Instrument } \\
\text { depth }\end{array}$ & Data time period (from-to) & ID & $\begin{array}{l}\text { Lat, lon, } \\
\text { bottom depth }\end{array}$ & $\begin{array}{l}\text { Instrument } \\
\text { depth }\end{array}$ & Data time period (from-to) \\
\hline \multicolumn{8}{|c|}{ BIO moorings } \\
\hline 1121 & $\begin{array}{l}43^{\circ} 05.940^{\prime} \mathrm{N} \\
49^{\circ} 01.980^{\prime} \mathrm{W} \\
1493 \mathrm{~m}\end{array}$ & $\begin{array}{r}381 \\
785 \\
1391\end{array}$ & $\begin{array}{l}1 \text { Aug 1993-11 Sep } 1993 \\
1 \text { Aug 1993-21 Aug } 1993 \\
1 \text { Aug 1993-5 Sep } 1994\end{array}$ & 1122 & $\begin{array}{l}43^{\circ} 04.020^{\prime} \mathrm{N} \\
48^{\circ} 37.980^{\prime} \mathrm{W} \\
2449 \mathrm{~m}\end{array}$ & $\begin{array}{r}330 \\
734 \\
1440\end{array}$ & $\begin{array}{l}1 \text { Aug } 1993-1 \text { Jul } 1995 \\
1 \text { Aug 1993-1 Jul } 1995 \\
1 \text { Aug } 1993-1 \text { Jul } 1995\end{array}$ \\
\hline 1123 & $\begin{array}{l}42^{\circ} 57.060^{\prime} \mathrm{N} \\
48^{\circ} 10.980^{\prime} \mathrm{W} \\
3262 \mathrm{~m}\end{array}$ & $\begin{array}{r}346 \\
751 \\
1456 \\
2461 \\
3162\end{array}$ & $\begin{array}{r}11 \text { Aug } 1993-3 \text { May } 1995 \\
2 \text { Aug 1993-3 May } 1995 \\
2 \text { Aug 1993-3 May } 1995 \\
2 \text { Aug 1993-2 Apr } 1995 \\
2 \text { Aug 1993-2 Apr } 1995\end{array}$ & 1124 & $\begin{array}{l}42^{\circ} 43.020^{\prime} \mathrm{N} \\
47^{\circ} 23.100^{\prime} \mathrm{W} \\
3894 \mathrm{~m}\end{array}$ & $\begin{array}{r}381 \\
786 \\
1492 \\
2497 \\
3494 \\
3794\end{array}$ & $\begin{array}{l}2 \text { Aug 1993-30 Jun } 1995 \\
2 \text { Aug 1993-30 Jun } 1995 \\
2 \text { Aug 1993-30 Jun } 1995 \\
2 \text { Aug 1993-30 Jun } 1995 \\
2 \text { Aug 1993-2 Jul } 1995 \\
2 \text { Aug 1993-2 Jul } 1995\end{array}$ \\
\hline 1125 & $\begin{array}{l}42^{\circ} 33.960^{\prime} \mathrm{N} \\
46^{\circ} 41.160^{\prime} \mathrm{W} \\
4392 \mathrm{~m}\end{array}$ & $\begin{array}{r}377 \\
782 \\
1488 \\
2493 \\
3490 \\
4292\end{array}$ & $\begin{array}{l}3 \text { Aug 1993-1 Mar } 1995 \\
3 \text { Aug 1993-1 Mar } 1995 \\
3 \text { Aug 1993-1 Mar } 1995 \\
3 \text { Aug 1993-1 Mar } 1995 \\
3 \text { Aug 1993-1 Mar } 1995 \\
3 \text { Aug 1993-1 Mar } 1995\end{array}$ & 1126 & $\begin{array}{l}42^{\circ} 15.180^{\prime} \mathrm{N} \\
46^{\circ} 00.300^{\prime} \mathrm{W} \\
4701 \mathrm{~m}\end{array}$ & $\begin{array}{r}409 \\
814 \\
1519 \\
2518 \\
3509 \\
4006 \\
4601\end{array}$ & $\begin{array}{l}4 \text { Aug 1993-2 May } 1995 \\
4 \text { Aug 1993-2 May } 1995 \\
4 \text { Aug 1993-2 May } 1995 \\
4 \text { Aug 1993-19 Aug } 1994 \\
4 \text { Aug 1993-2 May } 1995 \\
4 \text { Aug 1993-2 Sep } 1994 \\
4 \text { Aug 1993-2 May } 1995\end{array}$ \\
\hline 1127 & $\begin{array}{l}42^{\circ} 06.060^{\prime} \mathrm{N} \\
45^{\circ} 19.020^{\prime} \mathrm{W} \\
4786 \mathrm{~m}\end{array}$ & $\begin{array}{r}374 \\
779 \\
2488 \\
3486 \\
3988 \\
4686\end{array}$ & $\begin{array}{l}4 \text { Aug 1993-27 Feb } 1995 \\
4 \text { Aug 1993-28 Nov } 1994 \\
4 \text { Aug 1993-27 Feb } 1995 \\
4 \text { Aug 1993-27 Feb } 1995 \\
4 \text { Aug 1993-18 Nov } 1994 \\
4 \text { Aug 1993-27 Feb } 1995\end{array}$ & 1128 & $\begin{array}{l}41^{\circ} 54.420^{\prime} \mathrm{N} \\
44^{\circ} 34.500^{\prime} \mathrm{W} \\
4888 \mathrm{~m}\end{array}$ & $\begin{array}{r}416 \\
1526 \\
3528 \\
4029 \\
4788\end{array}$ & $\begin{array}{l}5 \text { Aug } 1993-1 \text { May } 1995 \\
5 \text { Aug } 1993-1 \text { May } 1995 \\
5 \text { Aug 1993-1 May } 1995 \\
5 \text { Aug 1993-1 May } 1995 \\
5 \text { Aug 1993-1 May } 1995\end{array}$ \\
\hline \multicolumn{8}{|c|}{ IfM Kiel moorings } \\
\hline K101 & $\begin{array}{l}43^{\circ} 04.000^{\prime} \mathrm{N} \\
48^{\circ} 52.500^{\prime} \mathrm{W} \\
2002 \mathrm{~m}\end{array}$ & $\begin{array}{r}502 \\
1247 \\
1961\end{array}$ & $\begin{array}{l}28 \text { Jul } 1999-11 \text { May } 2001 \\
28 \text { Jul 1999-11 May } 2001 \\
28 \text { Jul 1999-11 May } 2001\end{array}$ & K102 & $\begin{array}{l}42^{\circ} 57.000^{\prime} \mathrm{N} \\
48^{\circ} 23.700^{\prime} \mathrm{W} \\
3000 \mathrm{~m}\end{array}$ & $\begin{array}{r}501 \\
1497 \\
2248 \\
2961\end{array}$ & $\begin{array}{l}28 \text { Jul } 1999-11 \text { May } 2001 \\
28 \text { Jul } 1999-11 \text { May } 2001 \\
28 \text { Jul } 1999-11 \text { May } 2001 \\
28 \text { Jul } 1999-11 \text { May } 2001\end{array}$ \\
\hline K103 & $\begin{array}{l}42^{\circ} 46.800^{\prime} \mathrm{N} \\
47^{\circ} 45.200^{\prime} \mathrm{W} \\
3640 \mathrm{~m}\end{array}$ & $\begin{array}{l}1457 \\
2962 \\
3571\end{array}$ & $\begin{array}{l}29 \text { Jul } 1999-12 \text { May } 2001 \\
29 \text { Jul 1999-12 May } 2001 \\
29 \text { Jul 1999-12 May } 2001\end{array}$ & K104 & $\begin{array}{l}42^{\circ} 43.100^{\prime} \mathrm{N} \\
46^{\circ} 47.500^{\prime} \mathrm{W} \\
4310 \mathrm{~m}\end{array}$ & $\begin{array}{l}1498 \\
2249 \\
2998 \\
3753 \\
4211\end{array}$ & $\begin{array}{l}30 \text { Jul } 1999-12 \text { May } 2001 \\
30 \text { Jul } 1999-12 \text { May } 2001 \\
30 \text { Jul } 1999-12 \text { May } 2001 \\
30 \text { Jul 1999-12 May } 2001 \\
30 \text { Jul 1999-12 May } 2001\end{array}$ \\
\hline
\end{tabular}

the water column. The resulting profiles were interpolated horizontally using a 30-km half-width and 70-km cutoff to obtain daily cross sections of velocity on a $100 \mathrm{~m}$ by $10 \mathrm{~km}$ grid. Last, time series of volume transport were determined.

The mean vectors from all instruments (including the means from the IfM array) show the deep-reaching NAC at stations $1125-1128$ still exceeds $10 \mathrm{~cm} \mathrm{~s}^{-1}$ at $4000-$ $m$ depth, and the DWBC west of stations 1125/K104 (Fig. 5 and Table 2). The core of the NAC is located at stations 1126 and 1127, while at the offshore mooring 1128 the mean flow has a shoreward component, indicating a sharpening of the NAC core. West of the $\mathrm{NAC}$, there is an indication of a shallow northward mean flow at the top instrument of station 1123 (Figs. 4a and 5). The maximum DWBC speed is centered at stations $1125 / \mathrm{K} 104$, but the mean southward flow reaches up to the shallowest levels at the western end of the section.

\section{b. The 1999-2001 moored array}

The moored IfM Kiel array, consisting of four stations, K101-K104 (Fig. 2 and Table 1), was designed to cover the cold water outflow offshore from the Grand Banks and was based on the mean current section derived from the BIO array and inverted echosounders (IESs) by Meinen (2001). The inshore mooring, in the permanent outflow core of the subpolar gyre, was located at the 1800-m isobath. The offshore one, repeating the location of BIO mooring 1125 at the 4100 -m isobath, extended upward to $1500 \mathrm{~m}$ (Fig. 3). Overall, the array consisted of 14 Aanderaa rotor current meters (RCMs) and 1 FSI acoustic current meter. All current meters carried temperature sensors, and some of the RCMs were equipped with pressure sensors to monitor mooring motion.

Mooring K101, located between the positions of BIO moorings 1121 and 1122, shows southward flow most of the time over the entire depth range covered (Figs. $6 a, b)$. The deep instruments of K102-K104 also show dominant southward flow with strong superimposed variability (Fig. 6b), as seen in the earlier BIO array (Fig. 4b). At the upper instruments of the three outer stations the NAC is present but is not adequately covered by this array, with K103 and K104 only reaching up to the 
(a) BIO Array - Rotated Currents at $800 \mathrm{~m}$ level

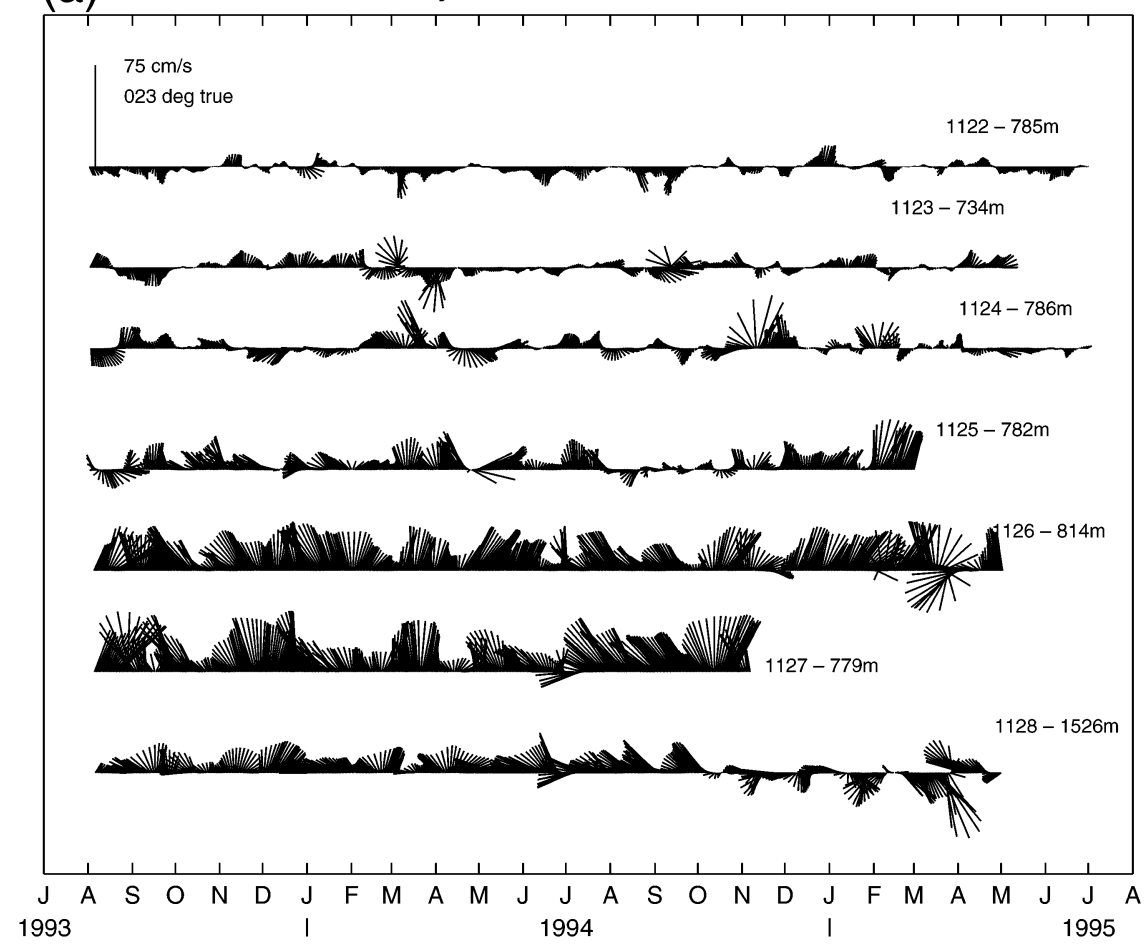

(b) BIO Array - Rotated Currents near bottom

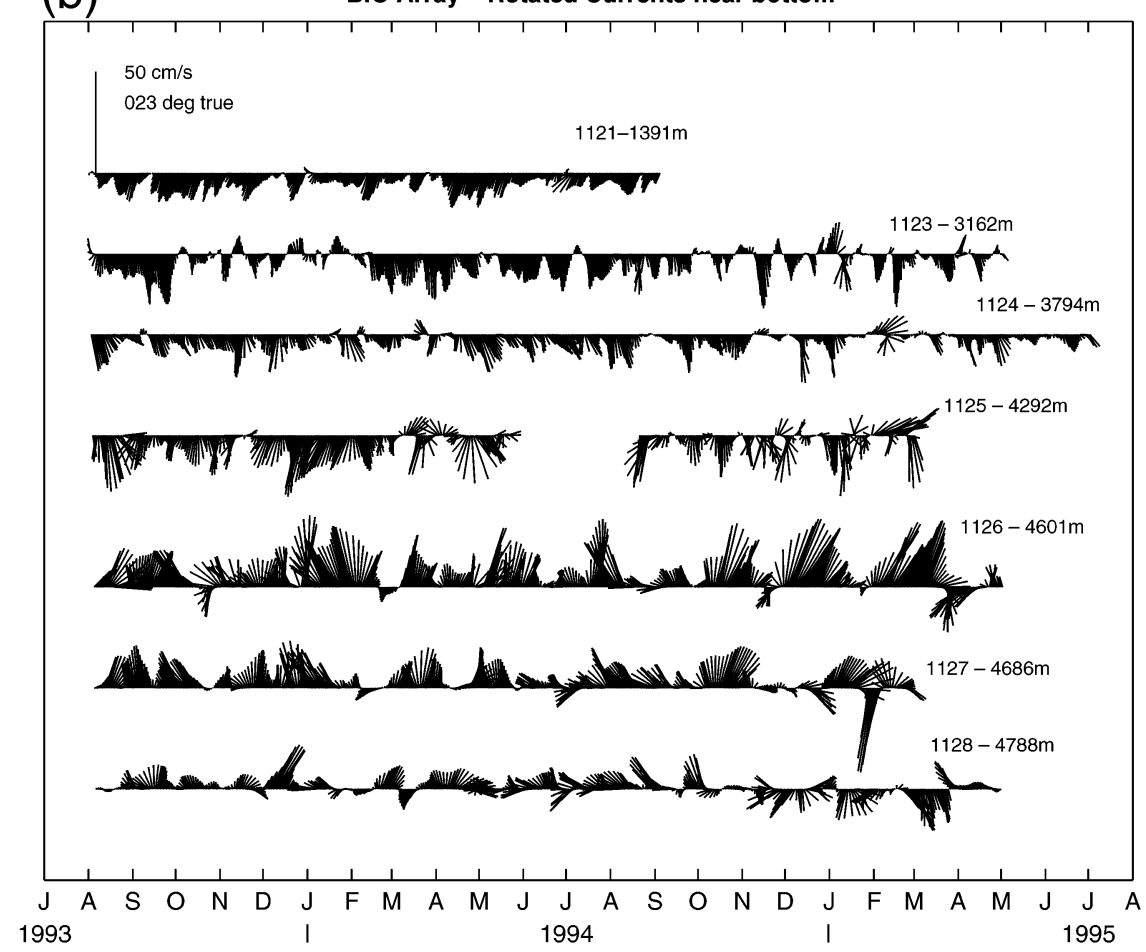

FIG. 4. Time series of low-passed current-vector time series (fluctuations shorter than 3 days suppressed) for Aug 1993-Jun 1995, recorded at moorings 1122-1128, (a) at approximately 800$\mathrm{m}$ level and (b) at near-bottom locations (Fig. 3); vectors rotated to $23^{\circ} \mathrm{T}$ so that outflow parallel to boundary is downward. 


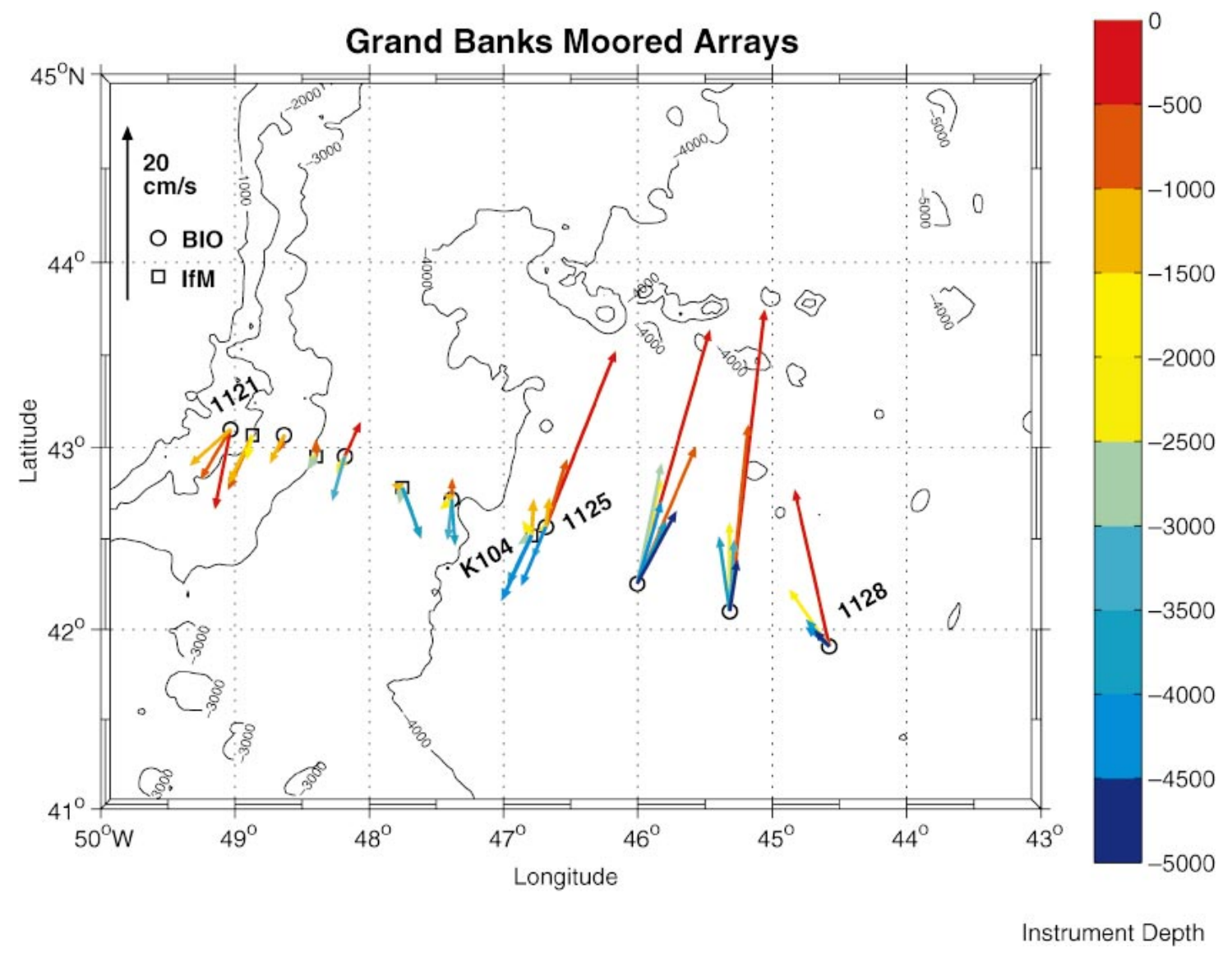

FIG. 5. Record-length mean vectors of BIO (circles) and IfM moorings (squares). Instrument depths are color coded.

1500-m level (Fig. 3). In addition to the strong mesoscale variability, longer-period variations are also apparent: for example, while K104 showed a steady increase of the southward deep flow during the second half of the deployment period, the southward bottom currents of K103 showed a maximum near the middle of the deployment period and a decrease toward the end (Fig. 6b).

\section{c. Shipboard observations 1999-2001}

\section{1) VESSEL-MOUNTED AND LOWERED ADCPS}

During the mooring deployment cruise of RV Meteor (M45/3), spanning 27 July-1 August 1999, shipboard ADCP measurements were taken with an RD Instruments (RDI) 75-kHz narrowband unit having a depth range in this region of about $600 \mathrm{~m}$. The vertical resolution of the shipboard ADCP data was $16 \mathrm{~m}$, with the uppermost reliable depth cell located at $29 \mathrm{~m}$ below the surface and the estimated accuracy of the hourly averages being $3 \mathrm{~cm} \mathrm{~s}^{-1}$. At the mooring retrieval time, during 11-12 May 2001 (cruise M50/1), the ship was equipped with a 75-kHz RDI Ocean Surveyor, a phased array Doppler type having an observational range extending down to about $700 \mathrm{~m}$ (Fischer et al. 2003).
Because of the increased quality of the acoustic measurements and the improved navigation data we estimate the error for hourly mean data during the second section to be $2 \mathrm{~cm} \mathrm{~s}^{-1}$. Again, the first reliable depth cell was located at a depth of $29 \mathrm{~m}$.

After applying standard postprocessing routines, the barotropic tidal currents of six major constituents were removed from 10-min ensembles by using the harmonics of the FES tidal model (C. LeProvost 2001, personal communication). Then the data were averaged onto a 20-km grid along the section, with each grid point containing data collected over at least $1 \mathrm{~h}$. The measurement error of the gridded velocity data from both ADCP sections was estimated be less than $2 \mathrm{~cm} \mathrm{~s}^{-1}$.

To sample the deeper currents an ADCP was lowered (LADCP) together with the CTD at all stations along the section. The instrument used during both cruises was a deep sea version of the classical $150-\mathrm{kHz}$ narrowband RD Instruments ADCP. During postprocessing, the average velocity profile was calculated from each individual profile by solving an inverse problem that included onstation data from the vessel-mounted ADCPs, similar to the procedure described by Visbeck (2002). The accuracy of the LADCP data is estimated to be $2 \mathrm{~cm} \mathrm{~s}^{-1}$ for the depth-integrated currents and about $5 \mathrm{~cm} \mathrm{~s}^{-1}$ for the bar- 
TABLE 2. Grand Banks-BIO current-meter statistics.

\begin{tabular}{|c|c|c|c|c|c|c|c|c|}
\hline \multirow[b]{2}{*}{ ID } & \multirow{2}{*}{$\begin{array}{c}\text { Lat }\left({ }^{\circ} \mathrm{N}\right) \text {, } \\
\text { lon }\left({ }^{\circ} \mathrm{W}\right), \\
\text { bottom }(\mathrm{m})\end{array}$} & \multirow[b]{2}{*}{ Depth (m) } & \multirow{2}{*}{$\begin{array}{l}\text { Record length } \\
\text { (days) }\end{array}$} & $\bar{u}$ & $\delta u$ & $\bar{v}$ & $\delta v$ & \multirow[b]{2}{*}{$\operatorname{EKE}\left(\mathrm{cm}^{2} \mathrm{~s}^{-2}\right)$} \\
\hline & & & & \multicolumn{4}{|c|}{$\left(\right.$ rotated $\left.23^{\circ}\right)\left(\mathrm{cm} \mathrm{s}^{-1}\right)$} & \\
\hline \multicolumn{9}{|c|}{ (a) BIO moorings } \\
\hline \multirow[t]{3}{*}{1121} & 43.099 & 381 & 41.0 & 2.23 & 4.96 & -10.51 & 5.36 & 26.66 \\
\hline & 49.033 & 785 & 20.5 & -1.06 & 2.98 & -7.62 & 5.43 & 19.21 \\
\hline & 1493 & 1391 & 400.0 & -3.08 & 2.25 & -6.55 & 4.49 & 12.60 \\
\hline \multirow[t]{3}{*}{1122} & 43.067 & 330 & 699.0 & 0.22 & 4.52 & 0.00 & 8.47 & 46.03 \\
\hline & 48.633 & 734 & 699.0 & 0.17 & 2.54 & -2.39 & 5.60 & 18.90 \\
\hline & 2449 & 1440 & 699.0 & -0.29 & 2.68 & -4.20 & 4.58 & 14.06 \\
\hline \multirow[t]{5}{*}{1123} & 42.951 & 346 & 630.5 & 0.18 & 7.86 & 5.05 & 10.81 & 89.32 \\
\hline & 48.183 & 751 & 639.5 & 0.22 & 5.47 & 0.55 & 7.19 & 40.80 \\
\hline & 3262 & 1456 & 415.0 & 0.17 & 5.30 & -1.90 & 6.94 & 38.14 \\
\hline & & 2461 & 608.0 & -0.04 & 2.81 & -2.59 & 5.24 & 17.68 \\
\hline & & 3162 & 639.0 & 0.77 & 2.34 & -6.08 & 7.97 & 34.53 \\
\hline \multirow[t]{5}{*}{1124} & 42.717 & 786 & 697.0 & -1.07 & 6.79 & 2.56 & 8.39 & 58.24 \\
\hline & 47.385 & 1492 & 697.0 & -1.26 & 5.66 & 0.36 & 6.94 & 40.10 \\
\hline & 3894 & 2497 & 696.5 & -0.94 & 4.83 & -1.92 & 5.76 & 28.26 \\
\hline & & 3494 & 698.5 & 1.57 & 5.03 & -5.18 & 5.77 & 29.32 \\
\hline & & 3794 & 699.0 & 2.79 & 3.88 & -5.51 & 5.55 & 22.94 \\
\hline \multirow[t]{6}{*}{1125} & 42.566 & 377 & 575.0 & -0.59 & 18.37 & 24.94 & 19.92 & 367.20 \\
\hline & 46.686 & 782 & 575.0 & -0.91 & 10.10 & 9.31 & 9.14 & 92.79 \\
\hline & 4392 & 1488 & 327.5 & -1.08 & 8.50 & 3.71 & 6.97 & 60.38 \\
\hline & & 2493 & 575.0 & -0.67 & 7.40 & -0.91 & 6.11 & 46.03 \\
\hline & & 3490 & 258.5 & 0.06 & 7.74 & -4.62 & 8.00 & 61.90 \\
\hline & & 4292 & 485.0 & 0.05 & 8.92 & -8.43 & 9.34 & 83.45 \\
\hline \multirow[t]{7}{*}{1126} & 42.253 & 409 & 636.0 & -4.26 & 24.47 & 34.59 & 25.00 & 611.83 \\
\hline & 46.005 & 814 & 636.0 & 0.02 & 13.42 & 19.68 & 11.46 & 155.66 \\
\hline & 4701 & 1519 & 636.0 & -2.56 & 10.63 & 14.03 & 9.43 & 101.01 \\
\hline & & 2518 & 334.0 & -3.25 & 11.83 & 15.89 & 8.69 & 107.73 \\
\hline & & 3509 & 636.0 & 0.26 & 8.77 & 9.14 & 8.65 & 75.81 \\
\hline & & 4006 & 394.0 & -1.29 & 9.49 & 11.22 & 8.12 & 77.98 \\
\hline & & 4601 & 636.0 & 1.01 & 10.87 & 10.82 & 10.89 & 118.32 \\
\hline \multirow[t]{6}{*}{1127} & 42.101 & 374 & 571.5 & -7.26 & 22.23 & 33.84 & 24.27 & 541.73 \\
\hline & 45.317 & 779 & 571.0 & -4.10 & 14.06 & 20.94 & 12.65 & 178.78 \\
\hline & 4786 & 2488 & 571.5 & -4.63 & 10.52 & 10.79 & 8.82 & 94.23 \\
\hline & & 3486 & 571.5 & -3.16 & 10.41 & 8.88 & 9.00 & 94.68 \\
\hline & & 3486 & 483.0 & -2.33 & 10.09 & 6.38 & 8.50 & 87.03 \\
\hline & & 4686 & 571.5 & -1.74 & 9.49 & 6.68 & 8.92 & 84.77 \\
\hline \multirow[t]{5}{*}{1128} & 41.907 & 416 & 633.5 & -12.32 & 30.41 & 17.24 & 27.45 & 839.05 \\
\hline & 44.575 & 1526 & 633.5 & -7.83 & 12.35 & 4.85 & 11.60 & 143.56 \\
\hline & 4888 & 3528 & 633.5 & -4.22 & 9.60 & 2.06 & 8.54 & 82.51 \\
\hline & & 4029 & 633.5 & -3.87 & 10.15 & 1.12 & 8.44 & 87.13 \\
\hline & & 4788 & 633.5 & -2.67 & 8.44 & 1.14 & 7.14 & 61.10 \\
\hline & & & & Kiel moo & & & & \\
\hline K101 & 43.067 & 502 & 652.5 & 0.17 & 3.73 & -7.07 & 5.11 & 20.01 \\
\hline & 48.875 & 1247 & 652.5 & -0.15 & 2.18 & -6.21 & 4.66 & 13.23 \\
\hline & 2002 & 1961 & 652.5 & 0.58 & 1,71 & -3.05 & 3.57 & 7.84 \\
\hline K102 & 42.950 & 501 & 653.0 & -0.62 & 4.45 & 1.76 & 7.36 & 37.00 \\
\hline & 48.395 & 1497 & 653.0 & -0.57 & 1.83 & -0.28 & 3.57 & 8.05 \\
\hline & 3000 & 2248 & 653.0 & -0.68 & 2.14 & -0.99 & 3.83 & 9.62 \\
\hline & & 2961 & 653.0 & -0.32 & 1.64 & -1.86 & 4.67 & 12.28 \\
\hline K103 & 42.780 & 1457 & 652.5 & -1.27 & 5.74 & 0.00 & 6.37 & 36.79 \\
\hline & 47.753 & 2962 & 652.5 & 0.40 & 2.87 & -1.86 & 3.76 & 11.18 \\
\hline & 3640 & 3571 & 652.5 & 4.38 & 4.59 & -4.69 & 4.94 & 22.71 \\
\hline K104 & 42.518 & 1498 & 652.0 & -1.41 & 6.76 & 3.99 & 6.61 & 44.71 \\
\hline & 46.792 & 2249 & 652.0 & -0.75 & 4.58 & 1.19 & 4.39 & 20.11 \\
\hline & 4310 & 2998 & 652.0 & -0.92 & 5.02 & -1.57 & 6.00 & 30.58 \\
\hline & & 3753 & 652.0 & -0.25 & 6.20 & -6.46 & 7.60 & 48.10 \\
\hline & & 4211 & 652.0 & -0.07 & 5.41 & -8.39 & 8.38 & 49.76 \\
\hline
\end{tabular}


(a)

IfM Array - Rotated Currents near 1500m

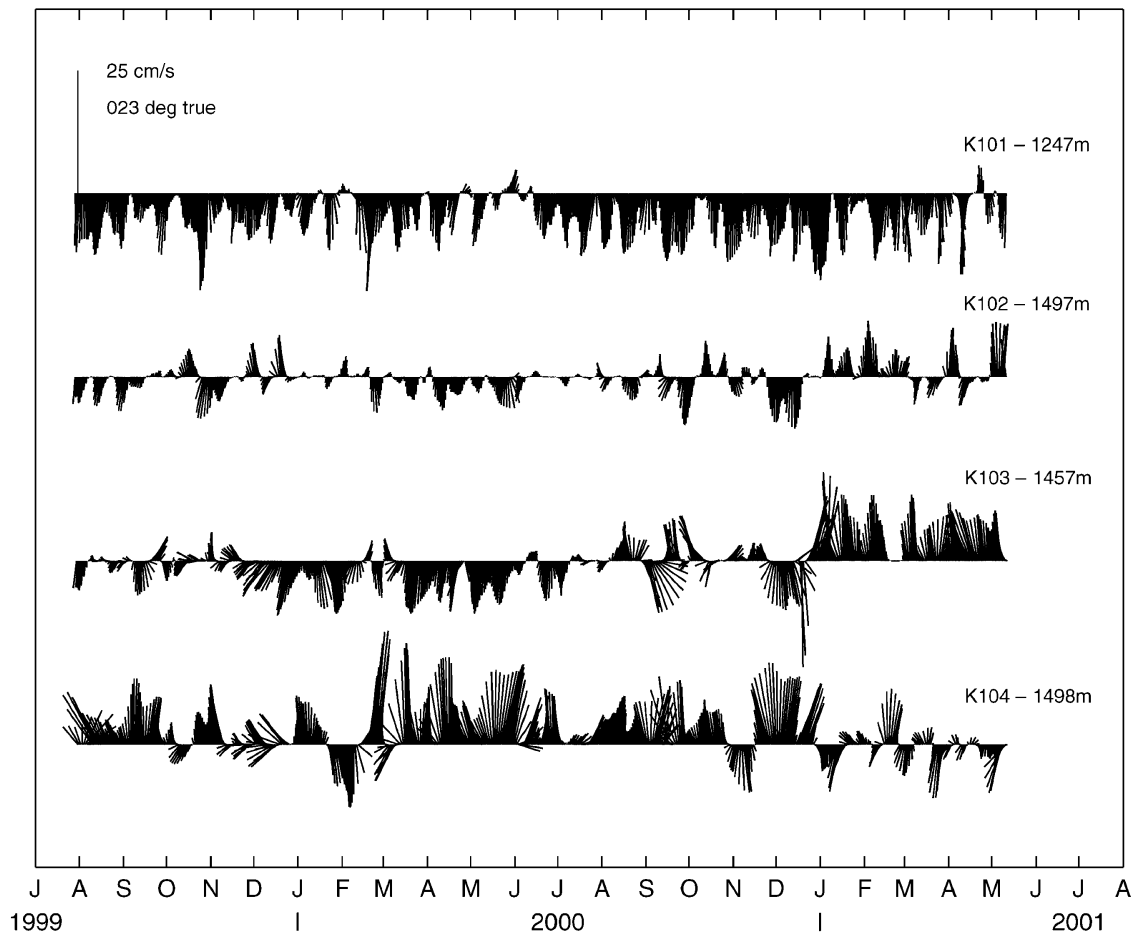

(b)

IfM Array - Rotated Currents near bottom

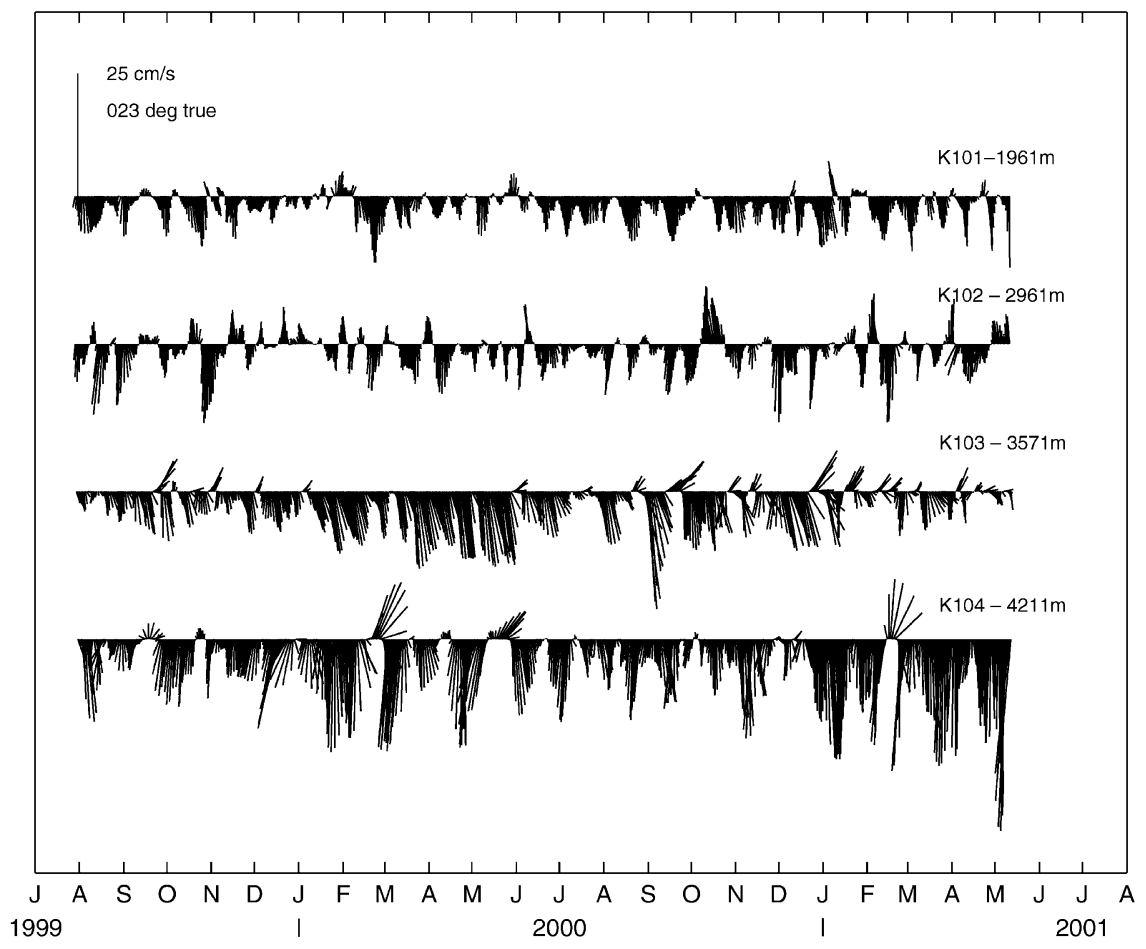

FIG. 6. Time series of low-passed current-vector time series from the IfM Kiel array for Aug 1999-May 2001, recorded at moorings K101-K104 (Fig. 3) for (a) 1250-1500-m depth range and (b) near-bottom locations; vector rotation as in Fig. 4. 


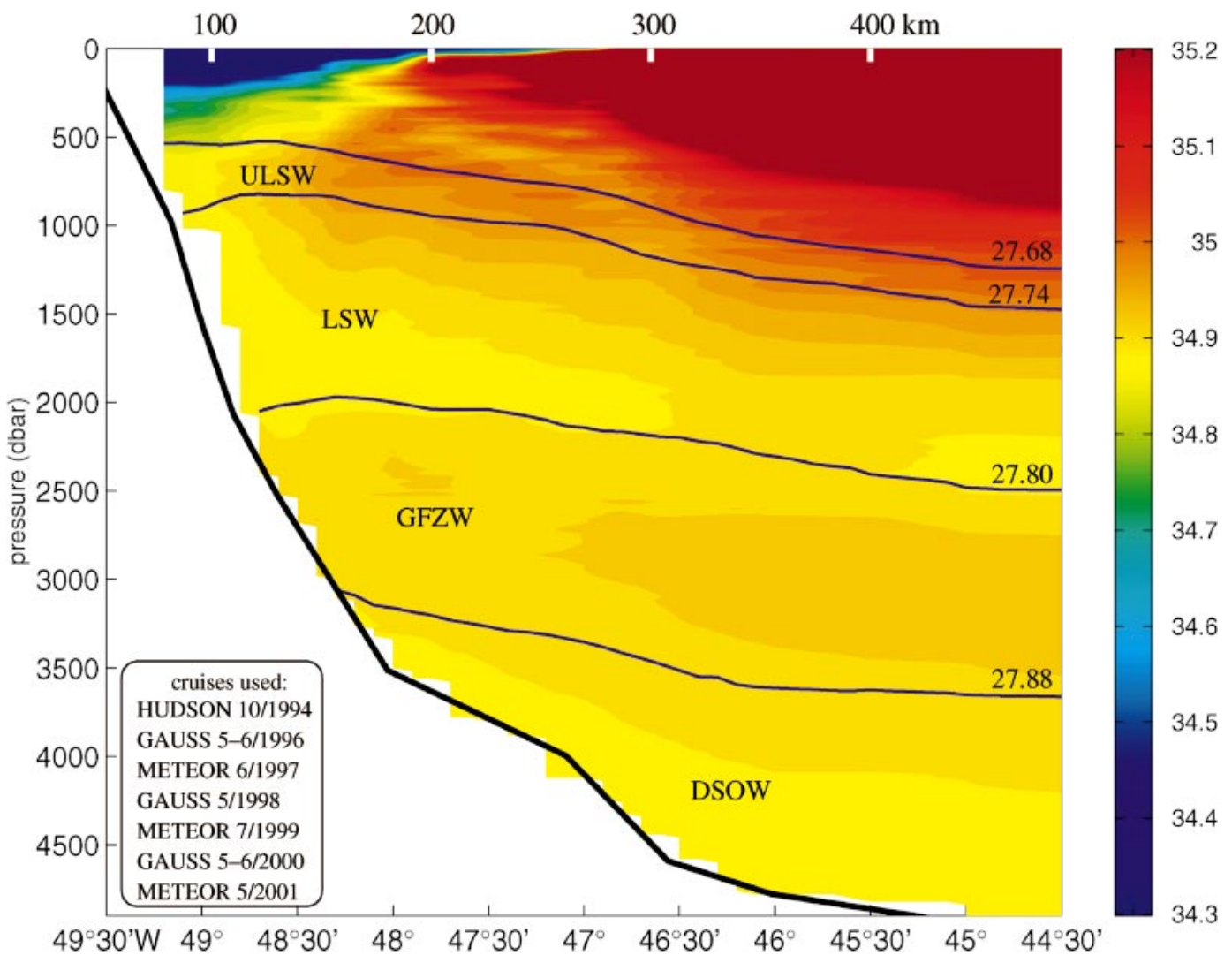

FIG. 7. Mean salinity section from seven CTD surveys (see inset) along the WOCE A2 line with superimposed isopycnals for separating the different North Atlantic Deep Water masses.

oclinic structure. For transport calculations, the barotropic tidal currents were removed from the velocity profiles as described above. Then the profiles were linearly interpolated onto the same horizontal grid as was used for the vessel-mounted ADCP data. Last, both direct velocity datasets were merged, applying a weight of 5 for the vessel-mounted ADCP data in the upper $500 \mathrm{~m}$ because of their higher accuracy and better horizontal resolution.

\section{2) HYDROGRAPHIC OBSERVATIONS}

Hydrographic observations on the Meteor cruises of 1999 and 2001 were carried out with a SeaBird SBE 9/ 11 CTD system. For both cruises the calibrated CTD salinities fall within 0.002 of the bottle salinities. In addition, data from five earlier hydrographic sections (listed in the inset of Fig. 7) were combined with the two recent surveys to construct a mean hydrographic section along the array. This served as a basis for deriving mean isopycnal depths for the layer transport calculation as well as for determining upper-layer shears. The geostrophic shears were used to expand the moored transport calculations from the top instrument levels toward the surface (see section 3 ). The mean isopycnals (Fig. 7) used for separating the upper LSW (uLSW),
LSW, Gibbs Fracture Zone Water (GFZW), and Denmark Strait Overflow Water (DSOW) are $\sigma_{\theta}=27.68$, $27.74,27.80$, and $27.88 \mathrm{~kg} \mathrm{~m}^{-3}$, respectively (SDSR). Core isopycnals selected for presenting water mass properties from these individual layers are 27.71, 27.77, 27.84 , and $27.885 \mathrm{~kg} \mathrm{~m}^{-3}$. Freon data were provided for both cruises by M. Rhein, and their accuracy is described in Rhein et al. (2002).

Standard deviations on those isopycnal depths from the seven sections (not shown) are $O( \pm 100 \mathrm{~m})$; so individual layer thicknesses can vary significantly (see also SDSR). Furthermore, the ship sections were typically taken during the summer, and seasonal biasing might be a factor. However, investigating the seasonal variability of isotherm depths throughout the moored array showed that at the depths of the isopycnals considered here, below about $500 \mathrm{~m}$, the effects were negligible. The upper-layer geostrophic shears, on the other hand, should definitely be affected by the summertime bias and, therefore, can only provide a guide, together with shear extrapolation, for estimating upper-layer transport contributions.

\section{The mean boundary current section}

Here we determine a mean current section from all moored observations, complemented for the upper layer 


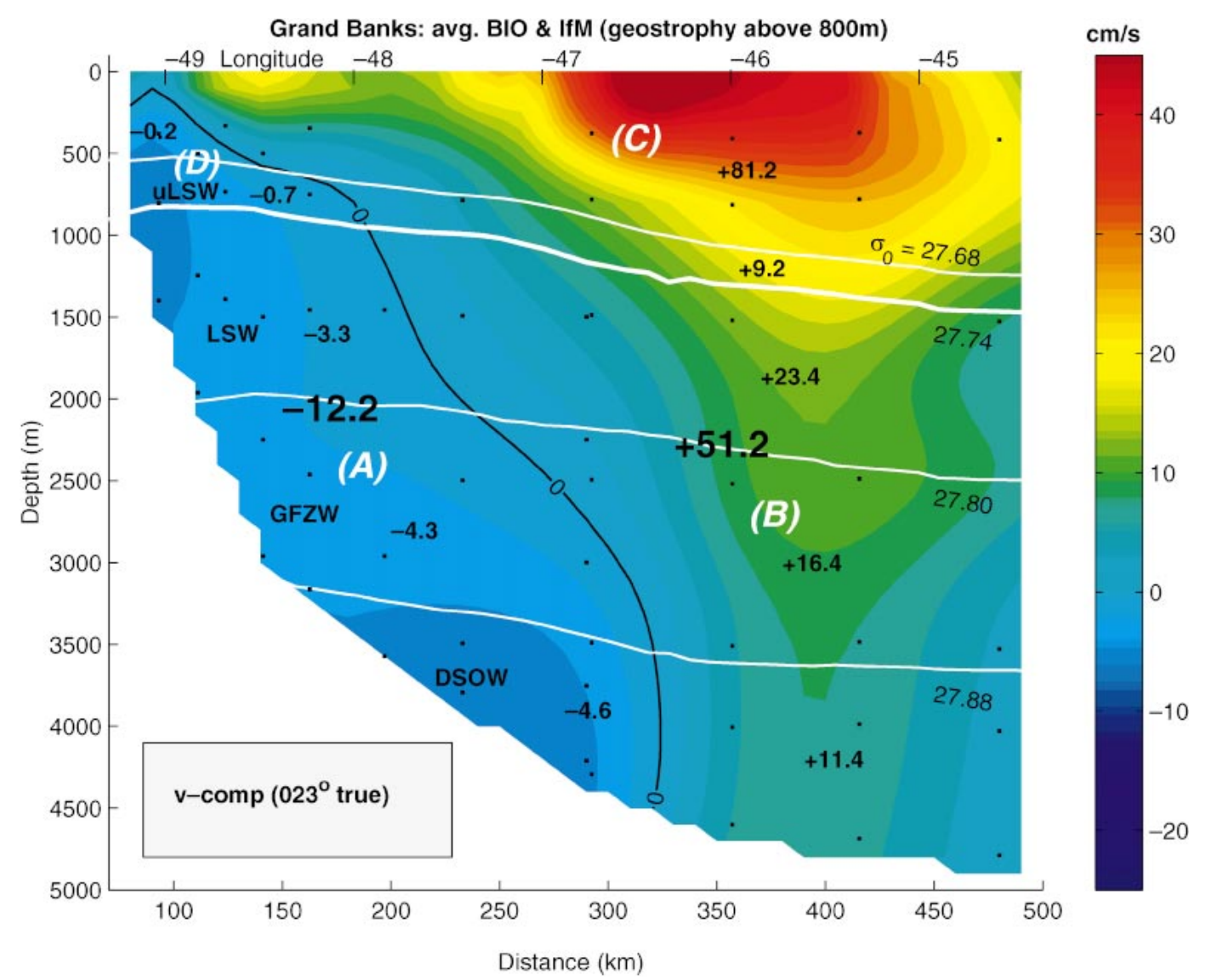

FIG. 8. Section of record-mean currents normal to the moored array line from the combined BIO and IfM arrays. Extrapolation from the $800-\mathrm{m}$ instrument level to the surface is carried out by geostrophic shears based on a mean shipboard hydrography section (seven section, see Fig. 7). Mean northward and southward transports through density layers identified for the different water masses are marked. Large-font numbers are integral southward and northward transports below the $27.74 \mathrm{~kg} \mathrm{~m}^{-3}$ isopycnal. Also marked (white) are subareas A-D used for calculating transport time series (see text for details).

by geostrophic shears derived from seven ship sections along the western end of the WOCE A2 line (SDSR). The mean currents from the combined arrays are extrapolated to the surface above the instrument level at $800 \mathrm{~m}$ using the geostrophic mean section. The result (Fig. 8) shows again the deep-reaching contributions of the NAC to the total northward transports and underscores the fact that the southward outflow across the section reaches up to the surface at the western side. The geostrophic upper-layer extrapolation causes a small secondary northward core closer to the boundary, which is also seen by the individual current-meter means at the top levels (Fig. 5). This feature is most likely due to the recirculation of the shallow Labrador Current retroflecting at the tail of the Grand Banks (A. Clarke 2003, personal communication).

The total mean northward flow through the section obtained with the geostrophic extrapolation from 800 $\mathrm{m}$ is $141.6 \mathrm{~Sv}$ (Table $3 \mathrm{~b}$ ), close to the value of $146 \mathrm{~Sv}$ derived by Meinen and Watts (2000). However, if extrapolation is used from above the $400-\mathrm{m}$ level to the surface, the total transport is lower, only $127.4 \mathrm{~Sv}$, and, if mapping extrapolation from the current meters alone is used above $400 \mathrm{~m}$, the NAC transport is even lower, 121.3 Sv. A possible reason for this difference from the 800-m extrapolation was pointed out to us by C. Meinen and A. Clarke (2003, personal communications). The rotor counters of the Aanderaa instruments at the top levels were set to a low maximum and multiple overruns were experienced. This made it difficult to detect the exact range the currents were in during high-velocity events, despite rather sophisticated attempts at correcting the problem. The end result might be a bias to lower mean values at the 400-m level, while at $800 \mathrm{~m}$ the problem could be corrected.

Along the western boundary, there are two deep current cores (Figs. 5 and 8). The shallower core, containing upper LSW (uLSW) and classical LSW, lies over the upper continental slope, while the deep one containing DSOW is recorded by moorings $1125 / \mathrm{K} 104$ over the 4300-m isobath. The total southward transport of LSW, GFZW, and DSOW below the density surface $\sigma_{\theta}$ 
TABLE 3. Mean volume transports (Sv) from combined BIO/IfM current-meter section.

\begin{tabular}{|c|c|c|c|c|c|c|}
\hline & \multicolumn{6}{|c|}{ Density range } \\
\hline & $<27.68$ & $27.68-27.74$ & $27.74-27.80$ & $27.80-27.88$ & $>27.88$ & Total \\
\hline \multicolumn{7}{|c|}{ (a) DWBC } \\
\hline From $800 \mathrm{~m}$ & -0.2 & -0.7 & -3.3 & -4.3 & -4.6 & -13.1 \\
\hline From $400 \mathrm{~m}$ & -0.7 & -0.9 & -3.3 & -4.3 & -4.6 & -13.8 \\
\hline \multicolumn{7}{|c|}{ (b) North Atlantic Current } \\
\hline From $800 \mathrm{~m}$ & 81.2 & 9.2 & 23.4 & 16.4 & 11.4 & 141.6 \\
\hline From $400 \mathrm{~m}$ & 67.1 & 9.1 & 23.4 & 16.4 & 11.4 & 127.4 \\
\hline
\end{tabular}

$=27.74 \mathrm{~kg} \mathrm{~m}^{-3}$, amounts to $12.2 \mathrm{~Sv}$, and only $0.7 \mathrm{~Sv}$ is added for the southward contribution by the upper LSW level in the density range $\sigma_{\theta}=27.68-27.74 \mathrm{~kg}$ $\mathrm{m}^{-3}$ (Table 3a). This result is almost unaffected by the change to geostrophic extrapolation from $400 \mathrm{~m}$ instead of from $800 \mathrm{~m}$ or if the vertical shear extrapolation from the moored profiles is applied. The total of $13 \mathrm{~Sv}$ below $\sigma_{\theta}=27.68 \mathrm{~kg} \mathrm{~m}^{-3}$ may be considered to be the export of NADW from the subpolar to the subtropical Atlantic. Eastward of this outflow, however, a northward flow of $51 \mathrm{~Sv}$ is carried by the deep part of the NAC (Table $3 b)$ for densities $\sigma_{\theta} \geqq 27.74 \mathrm{~kg} \mathrm{~m}^{-3}$. We will come back, in section 6 , to the issue of whether this northward flow is made up of the same water masses, that is, a recirculation of $\mathrm{DWBC}$, or whether there is a watermass distinction.

\section{Transport time series for 1993-95}

\section{a. Total, northward, and southward transports}

We do not have the database to determine temporal isopycnal layering on a day by day basis, and we therefore only estimated transport time series for the upper and deep water flow in fixed subareas, limited by the mean position of the $\sigma_{\theta}=27.74 \mathrm{~kg} \mathrm{~m}^{-3}$ isopycnal and by the contour of mean zero velocity from Fig. 8. Deep transports west of the zero isotach (subarea A) are associated with the DWBC as follows: subarea B corresponds to the deep NAC, subarea $\mathrm{C}$ to the upper NAC, and subarea $\mathrm{D}$ to the upper western boundary flow.

Transport time series from the 3-day low-pass-filtered currents of moorings 1122-1128 were determined for the northward and southward currents separately as well as for net contributions for the subregions just defined. Transports for the northward contributions show large fluctuations of more than $\pm 50 \mathrm{~Sv}$, associated with the NAC variability (Fig. 9). Transport variability for the southward contributions is much lower except for two spikes toward the end, the first one of which is due to the barotropic reversal at mooring 1128, as mentioned above. The means and standard deviations are $136.5 \pm$ 45.9 Sv (Table 4) for the total northward flow contributions, and $27.6 \pm 18.1 \mathrm{~Sv}$ for the southward flow. Both results are quite similar to the earlier estimates of
$140 \mathrm{~Sv}$ northward and $25 \mathrm{~Sv}$ southward, respectively, by Clarke et al. (1998). The small differences are presumably due to their different extrapolations to the surface and bottom.

Four events of extreme transport phases (marked IIV in the time series in Fig. 9) are shown in Fig. 10 to demonstrate that different flow patterns may cause comparable extremes of the transports. The typical situation for high NAC transports is shown in Fig. 10b with strong northward flow from top to bottom at stations 1126 and 1127. In late October 1993 (Fig. 10a) the NAC transport was low because all the currents across the section were low at the time. In contrast, in late January 1995 (Fig. 10d), the NAC was strong, but at the same time a strong southward flow offshore caused that transport minimum. One might be tempted to associate this situation with the superposition of the Mann Eddy (ME), but the entire northward flow through the section during event IV is only about $100 \mathrm{~Sv}$ (Fig. 9), too low for a mean NAC plus northward ME branch. Yet another minimum occurred in July 1994 (Fig. 10c) when currents in the NAC regime were strong but were oriented nearly normal to the mooring line.

As the northward and southward transport time series are based on all positive or negative contributions from section elements regardless of where they are, they are not representative of the NAC and DWBC flows alone. This is underscored when comparing the curve for total southward flow (green line in Fig. 9) with deep southward flow (dark blue): the big southward spikes were partially due to southward flow above $\sigma_{\theta}=27.74 \mathrm{~kg}$ $\mathrm{m}^{-3}$. Apparently these spikes were due to quasi-barotropic recirculation cells involving the warmer waters.

For the NAC, Fig. 11 shows the transport time series that is composed of both the upper (subarea C) and deep (subarea B) flow within the section associated with the mean (northward) NAC. Deep transports, below $\sigma_{\theta}=$ $27.74 \mathrm{~kg} \mathrm{~m}^{-3}$ through the entire section (in subareas A and B, Fig. 8) also show large variability (curve "total deep" in Fig. 11) because of the deep variability of the NAC (Table 4).

\section{b. The deep-water transports}

We obtain 22.2 Sv for the mean southward flow of waters below the $\sigma_{\theta}=27.74 \mathrm{~kg} \mathrm{~m}^{-3}$ isopycnal within 


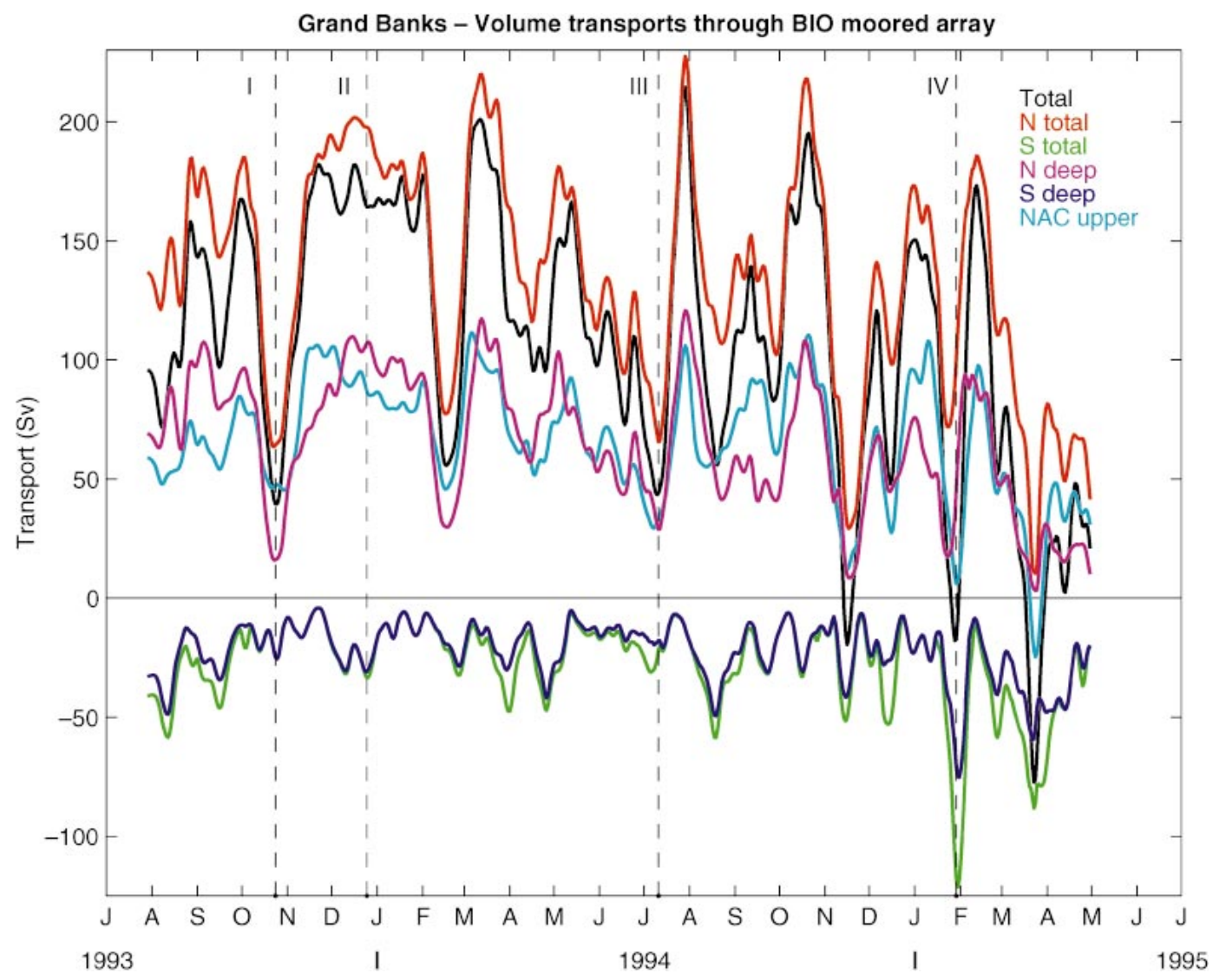

FIG. 9. Time series of total (black), total northward (red), and total southward (green) transports (Sv) 1993-95 through the BIO section; also shown are deep (below $\sigma_{\theta}=27.74 \mathrm{~kg} \mathrm{~m}^{-3}$; subareas A, B) northward (magenta), deep southward (dark blue), and upper NAC (subarea C, light blue). For locations of subareas see Fig. 8; marked I-IV are four extreme phases presented in Fig. 10.

the range covered by the entire BIO array (curve "S deep" in Fig. 9 and Table 4). When this number is compared with the total southward flow of 27.6 Sv (Table 4), a southward flow of $5.4 \mathrm{~Sv}$ is obtained for the density range above $\sigma_{\theta}=27.74 \mathrm{~kg} \mathrm{~m}^{-3}$. These contributions are mainly due to the southward bursts at the outer stations (see event IV, Figs. 9 and 10d).

As is also obvious from Fig. 9 and was already discussed in section 3, there is a large net northward deepwater transport of about $50 \mathrm{~Sv}$ below the NAC (Table 4; with the small transport differences against the NAC means of Fig. 8 due to the differences between averaging of the interpolated daily sections vs interpolating the mean section). Overall then, as already seen in the composite mean section, there must be a large southward deep-water flow somewhere in the western basin and east of BIO station 1128 (Fig. 2) in order to arrive at the approximately $15-\mathrm{Sv}$ net cross-sectional southward deep flow as required for the "conveyor belt" overturning circulation (Schmitz and McCartney 1993; Ganachaud and Wunsch 2000). One possible interpretation is the existence of a deep-reaching anticyclonic gyre (a deep Mann Eddy?) of some $30 \mathrm{~Sv}$ that returns the deep
NAC southward. As we will see later, the watermass signatures support the interpretation that the southward flow near the boundary is not recirculated by the deep NAC but carries different water masses.

TABLE 4. Mean and standard deviations of transport time series (Sv).

\begin{tabular}{lrr}
\hline \hline & $\begin{array}{r}\text { BIO array } \\
(1993-95)\end{array}$ & $\begin{array}{c}\text { IfM Kiel array } \\
(1999-2001)\end{array}$ \\
\hline Total north & $136.5 \pm 45.9$ & \\
Total south & $27.6 \pm 18.1$ & \\
Total section & $108.9 \pm 55.5$ & \\
& $65.8 \pm 25.0$ & \\
Upper NAC (C)* & $54.4 \pm 34.7$ & \\
Deep NAC (B)* & $61.5 \pm 23.4$ & \\
Deep NAC north (B)* & $7.2 \pm 11.6$ & \\
Deep NAC south (B)* & $120.2 \pm 56.7$ & \\
Total NAC (B + C)* & $3.7 \pm 3.8$ & $2.0 \pm 2.8$ \\
& $15.0 \pm 7.0$ & $13.2 \pm 6.5$ \\
DWBC north (A)* & $11.3 \pm 9.0$ & $11.2 \pm 7.4$ \\
DWBC south (A)* & $11.3 \pm 1.1$ & $11.2 \pm 0.9$ \\
Total DWBC (A)* & & \\
Total DWBC (A)* & & \\
(with error of means) & & \\
\hline
\end{tabular}

* For location of subareas see Fig. 8 and section $4 a$. 

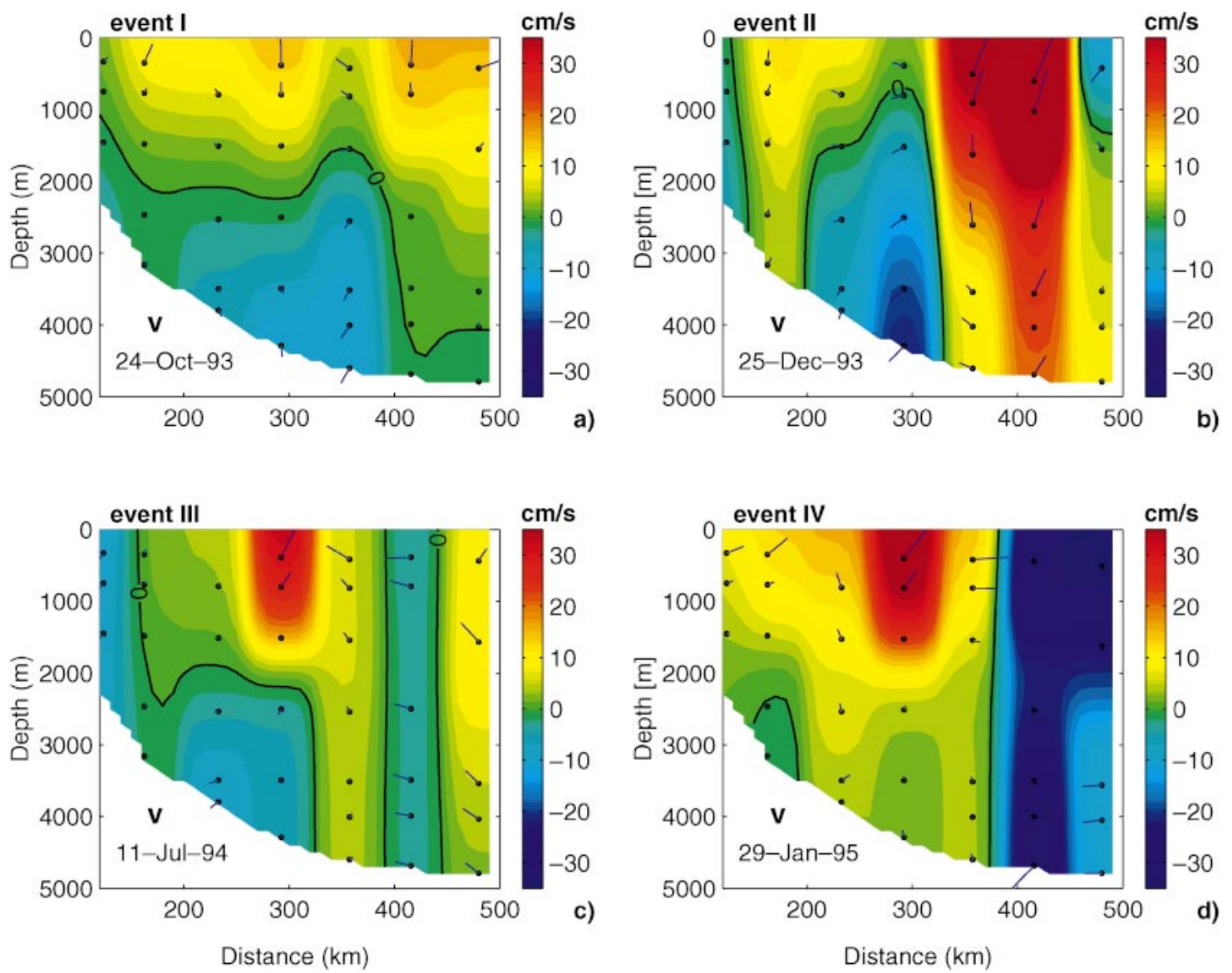

FIG. 10. Cross-sectional distribution of BIO array current vectors (up is toward $23^{\circ} \mathrm{T}$ ) and components normal to section (color coded) for events I-IV: 24 Oct 1993, 25 Dec 1993, 11 Jul 1994, and 29 Jan 1995 (see Fig. 9).

\section{c. Deep-water export observed by the inner part of the BIO array}

The 22.2 Sv of southward flow below $\sigma_{\theta}=27.74 \mathrm{~kg}$ $\mathrm{m}^{-3}$ within the reach of the entire BIO array include elements that clearly are associated with the deep-reaching NAC (and Mann Eddy) variability and therefore do not necessarily qualify as contributions to the deep-water outflow. It is of interest to determine that part of the flow below the $\sigma_{\theta}=27.74 \mathrm{~kg} \mathrm{~m}^{-3}$ isopycnal and west of the NAC axis that would be sampled by the 19992001 IfM array. We use subarea A in Fig. 8 for this calculation of DWBC transports. The mean southward transport is $15.0 \pm 7.0 \mathrm{~Sv}$ for this inner part (Table 4), which represents a large fraction of the mean southward deep-water flow observed by the full array. Through that inner part of the section there is also northward deep-water flow, of $3.7 \pm 3.8 \mathrm{~Sv}$, leaving a net total of deep outflow of $11.3 \pm 9.0 \mathrm{~Sv}$ (curve "DWBC" in Fig. 11) for the BIO array west of the NAC (subarea A in Fig. 8). The standard error of the mean is $\pm 1.1 \mathrm{~Sv}$ (Table 4) and has been calculated with the number of degrees of freedom determined from the decorrelation time scale.

This net mean of $11.3 \mathrm{~Sv}$ is the minimum of the deepwater export to the south since it is assumed that the entire amount of northward flow is due to reversals of the southward currents. If, however, some of the northward flowing water (3.7 Sv; Table 4) is made up of different watermass properties, the mean outflow will increase to a larger amount than the net of $11.3 \mathrm{~Sv}$.

The southward DWBC transports (Fig. 11) decrease over the 22-month-long observation period. The annual means decrease from 13.3 Sv southward in the first 12 months to $9.3 \mathrm{~Sv}$ in the last 12 months. This decrease reflects changes in DWBC currents, for example, at stations 1123 and 1124 (Fig. 4b). Fitting a linear trend to the 1993-95 DWBC transport time series (Fig. 11) would yield a transport decrease of $5.9 \mathrm{~Sv} \mathrm{yr}^{-1}$. The trend is robust and still exists if, for example, the large positive spike in February 1995 is removed. However, toward the end of the time series, transports drop back to about the 11-Sv mean value. We will come back to the trend discussion in the next section. 


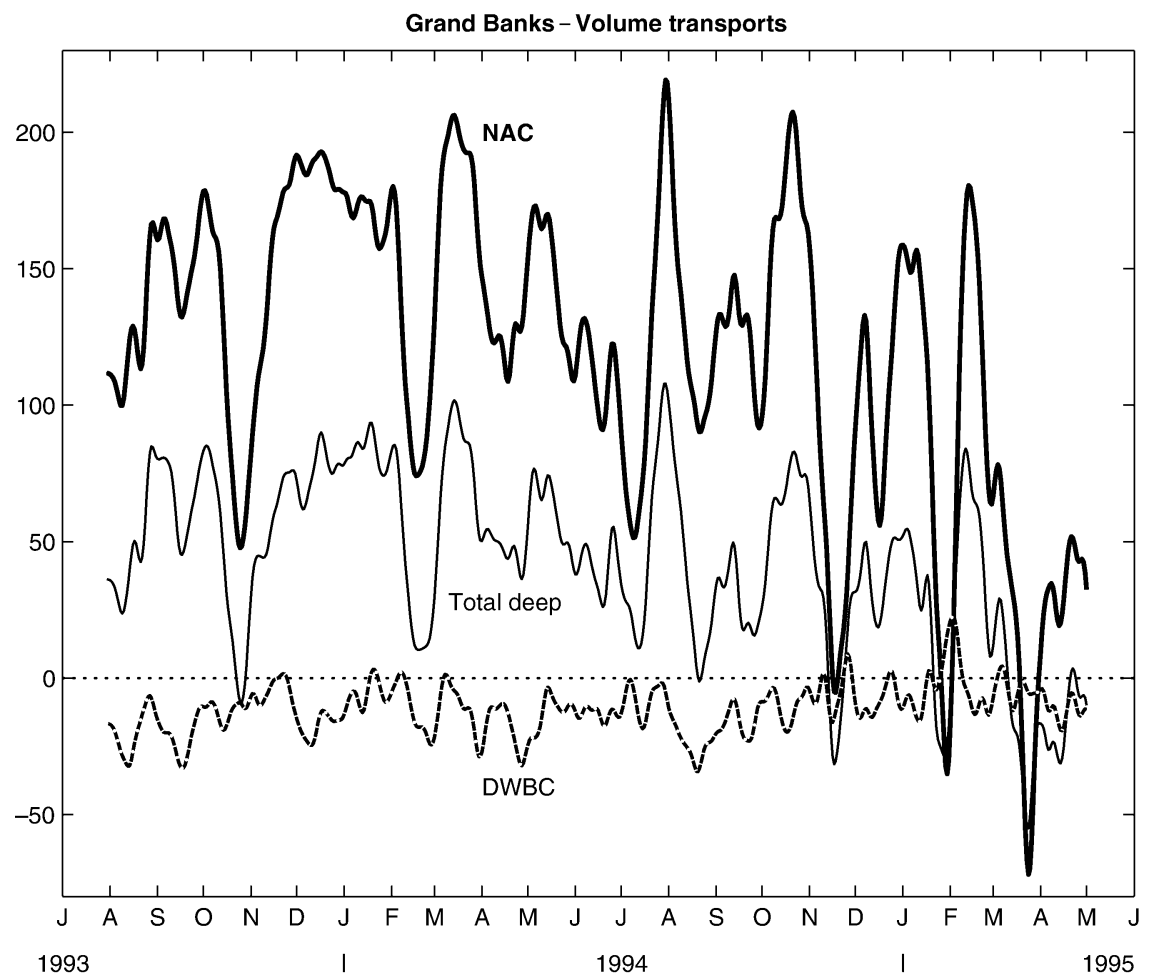

FIG. 11. Transport time series 1993-95 (Sv) of total NAC (thick line; subareas B, C), of deep water through the entire BIO array (thin line; subareas A, B), and of DWBC (dashed line; subarea A); for locations of subareas see Fig. 8 .

\section{d. Correlation patterns of NAC and DWBC}

As was already obvious from the current-vector plots (Fig. 4), large-scale correlated changes occur across the entire extent of the BIO array. This becomes more apparent from a correlation plot of the NAC transport (Fig. 11) with the alongshore current components at all mooring positions throughout the array (Fig. 12a). The 95\% significance level for the cross-correlations, as calculated using degrees of freedom determined from the decorrelation time scales of the respective time series (Sciremammano 1979), is approximately 0.5 for the cross section.

A nearly vertically oriented structure is apparent (Fig. $12 \mathrm{a}$ ) in which significant correlations at the $95 \%$ level are found for the core of the NAC east of about $46^{\circ} \mathrm{W}$ and the line of zero correlation occurs along the western edge of the mean NAC (Fig. 8). Although not significant, a large area of weak negative correlations is coinciding with the area covered by the mean DWBC (Fig. 8). Thus, northward transport anomalies of the NAC are associated with increased southward velocities of the DWBC. In contrast, negative NAC transport anomalies lead to weaker than normal DWBC currents.

For the deep-water transport time series of Fig. 11 maximum correlation is found in the entire western half of the section (Fig. 12b), upper and lower layers alike. Stronger than average southward DWBC transports result in reduced upper-layer NAC flow west of the NAC axis and enhanced flow in the entire NAC east of the axis. This implies that much of the DWBC transport variance is caused by the meandering of the NAC, a stronger DWBC transport when the NAC is located offshore and weaker vice versa.

This near-zonal modal pattern and NAC dominance are also the result from an EOF analysis in which independent deep variance, like a DWBC "pulsation mode," does not emerge and is thus not pursued further here.

The trend of the deep-water transport time series is also associated with NAC variability (Fig. 12c). In the western half of the section, the alongshore current components all have positive trends with increasing transports in the upper western NAC layer and decreasing transports in the DWBC and western shallow outflow (Fig. 8). In the NAC regime of moorings 1126-1128, all currents show decreasing trends with much steeper slopes than in the DWBC. The deep-water transport trend therefore is obviously not related to any kind of NADW source variability but is a consequence of NAC variability, explainable by a westward movement of the NAC during 1993-95. 

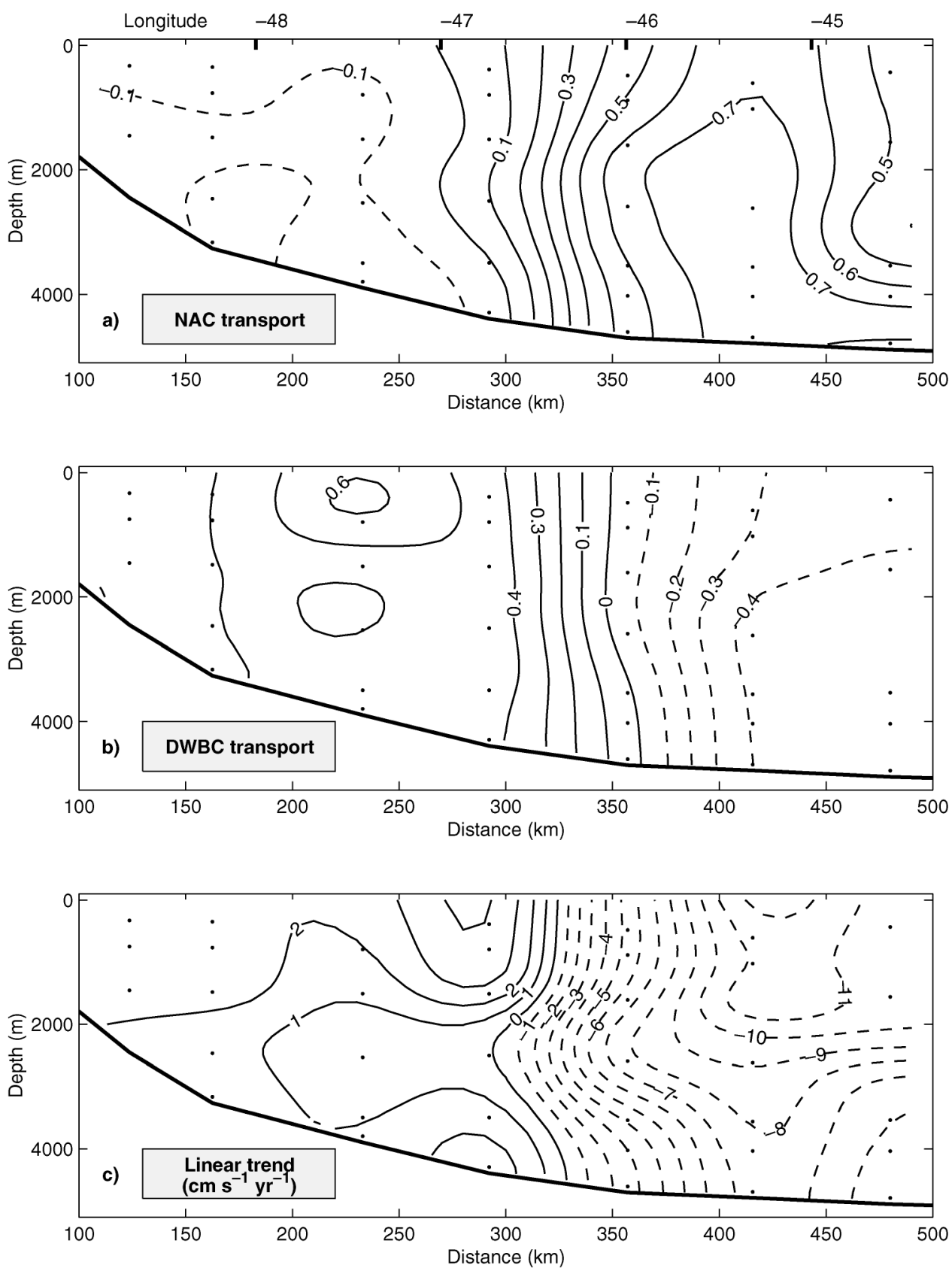

FIG. 12. (a) Correlation of current components normal to mooring section at all measurement points with NAC transport variability for 1993-95 observations. (b) As in (a) but for DWBC transport variability. (c) Linear trends $\left(\mathrm{cm} \mathrm{s}^{-1} \mathrm{yr}^{-1}\right)$ of current components normal to section.

\section{Transport variability from the 1999-2001 observations}

\section{a. Moored array transport time series}

The transport time series of the southward and northward cold water flows, again determined day by day for the array fraction below $\sigma_{\theta}=27.74 \mathrm{~kg} \mathrm{~m}^{-3}$ and west of the zero line of the mean section (subarea A, Fig. 8), from the IfM stations K101-K104, yield means of 13.2 $\pm 6.5 \mathrm{~Sv}$ for the southward deep-water flow and $2.0 \pm$ $2.8 \mathrm{~Sv}$ for the northward deep-water flow (Table 4). The difference between these two time series (Fig. 13a) is an estimate of the net deep-water transport along the western boundary, comparable to the BIO transport time series (Fig. 13b).

The mean southward transport through the IfM array and the error of the mean were obtained as $11.2 \pm 0.9$ $\mathrm{Sv}$ (Table 4). This is quite similar to the mean deep- 

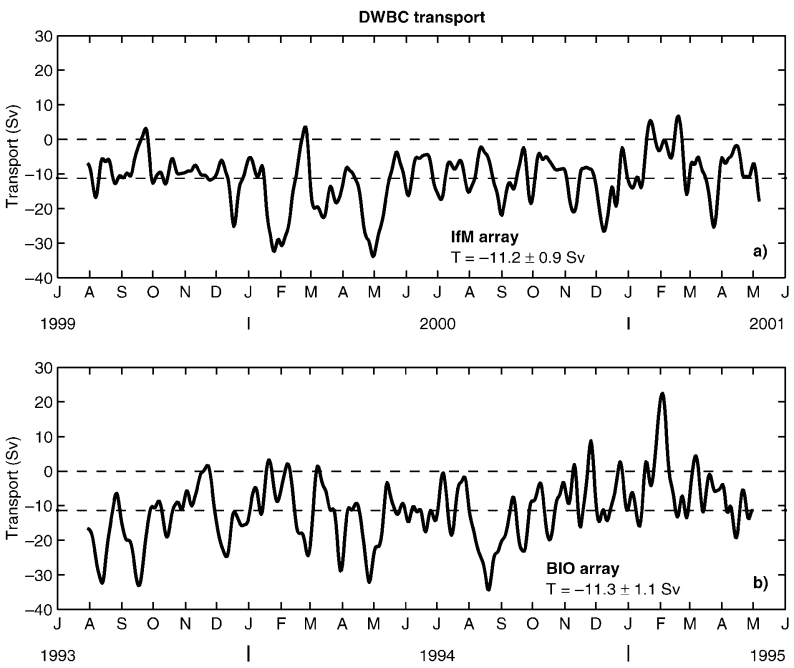

FIG. 13. (a) Time series of DWBC transports from 1999 to 2001 determined from the IfM array, stations K101-K104. (b) For comparison, time series of DWBC transports from 1993 to 1995 (curve DWBC in Fig. 11) is shown again; mean transports and standard errors of means are also shown.

water transport of $11.3 \pm 1.1 \mathrm{~Sv}$ that was calculated for the same subarea from the BIO array. However, a note of caution has to be applied concerning comparison of both means. Both arrays do not encompass exactly the same parts of the DWBC, and much open space in between the instruments is filled in by two-dimensional mapping.

In both transport time series there appears to be a spectral gap between the strong variability in the period range of 2 weeks to 2 months, and interannual to longerperiod variations (Fig. 13). For the IfM time series there is a slight decreasing trend of $1.7 \mathrm{~Sv} \mathrm{yr}^{-1}$. By contrast, as mentioned in sections $4 \mathrm{c}$ and $4 \mathrm{~d}$, the 1993-95 trans- port time series showed a much larger trend, but this was apparently associated with NAC variability, not NADW variations.

\section{b. Shipboard current observations in 1999 and 2001}

Drastic changes occurred between the current profiling sections from the deployment and retrieval cruises, as shown in Figs. 14a,b for the section west of $45.5^{\circ} \mathrm{W}$, together with layer transports between the previously selected isopycnals. In late July 1999, the front between the southward flowing deep water along the western continental slope and the northward flowing NAC was located approximately over the 4000-m isobath near $47^{\circ} \mathrm{W}$ at a distance of about $200 \mathrm{~km}$ from the shelf edge (Fig. 14a). As is obvious from this section, geostrophy calculations with any zero reference level would have yielded incorrect transports for the western part of the section.

In early May 2001 the southward deep-water flow along the continental margin was separated by northward flow near $48^{\circ} 20^{\prime} \mathrm{W}$ (Fig. 14b). There was stronger southward deep flow farther offshore and underneath the northward-flowing shallow core of the NAC. The total southward deep-water export west of $45.5^{\circ} \mathrm{W}$ and for densities $\sigma_{\theta}>27.74$ was $19.8 \mathrm{~Sv}$ in 1999 and 33.5 $\mathrm{Sv}$ in 2001. The northward transport through the section was $65.7 \mathrm{~Sv}$ in 1999 and it was 56.2 Sv in 2001, carried by the then much stronger but shallower NAC and the second northward branch to the west of it (Fig. 14b). Still, the NAC transport in both surveys was much below the mean of $140 \mathrm{~Sv}$ determined from the moored array.

For better comparison of the deep-water transports, Fig. 14, with the moored DWBC transport time series in Fig. 13, transport contributions were also calculated
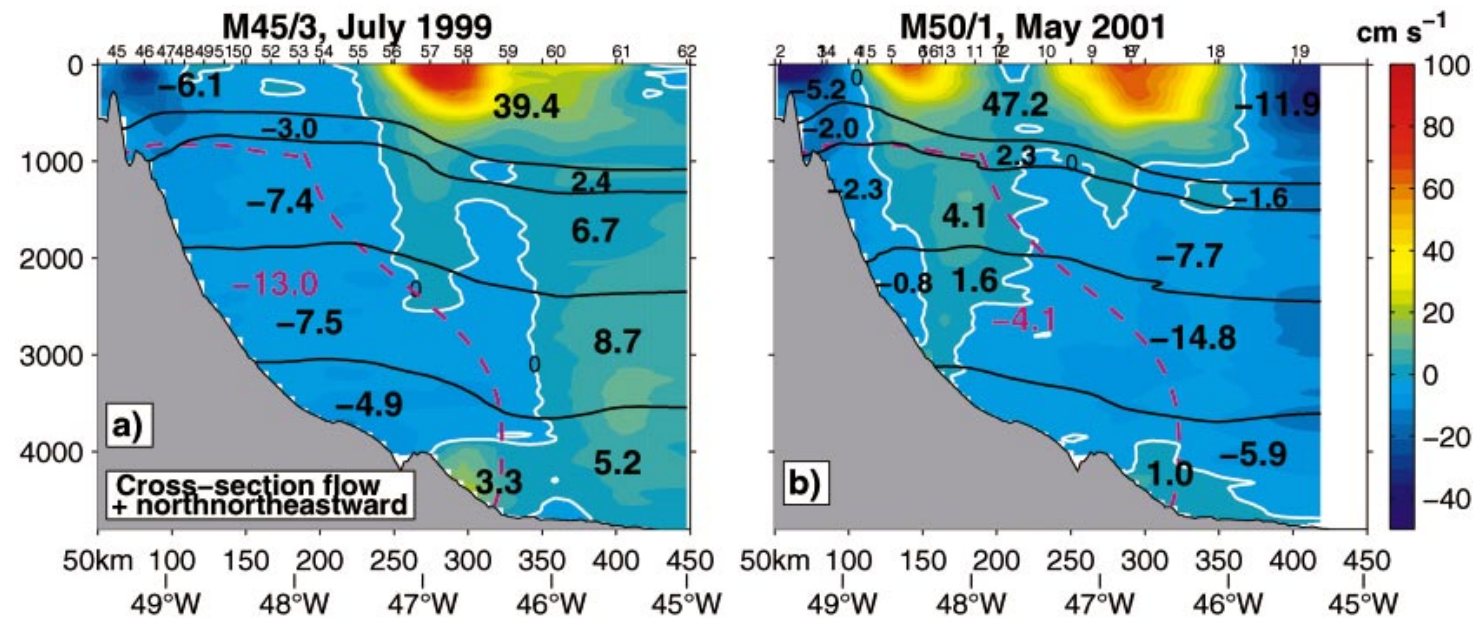

FIG. 14. Current component normal to the mooring section, measured by combined shipboard and lowered ADCPs during (a) cruise M45/3 from 27 Jul to 1 Aug 1999 and (b) cruise M50/1 from 11 to 12 May 2001. Transports (Sv) are shown for layers separated by isopycnals of $\sigma_{\theta}=27.68,27.74,27.80$, and $27.88 \mathrm{~kg} \mathrm{~m}^{-3}$. Also shown (dashed magenta line), for comparison with moored time series, are transports for subarea A (Fig. 8). 

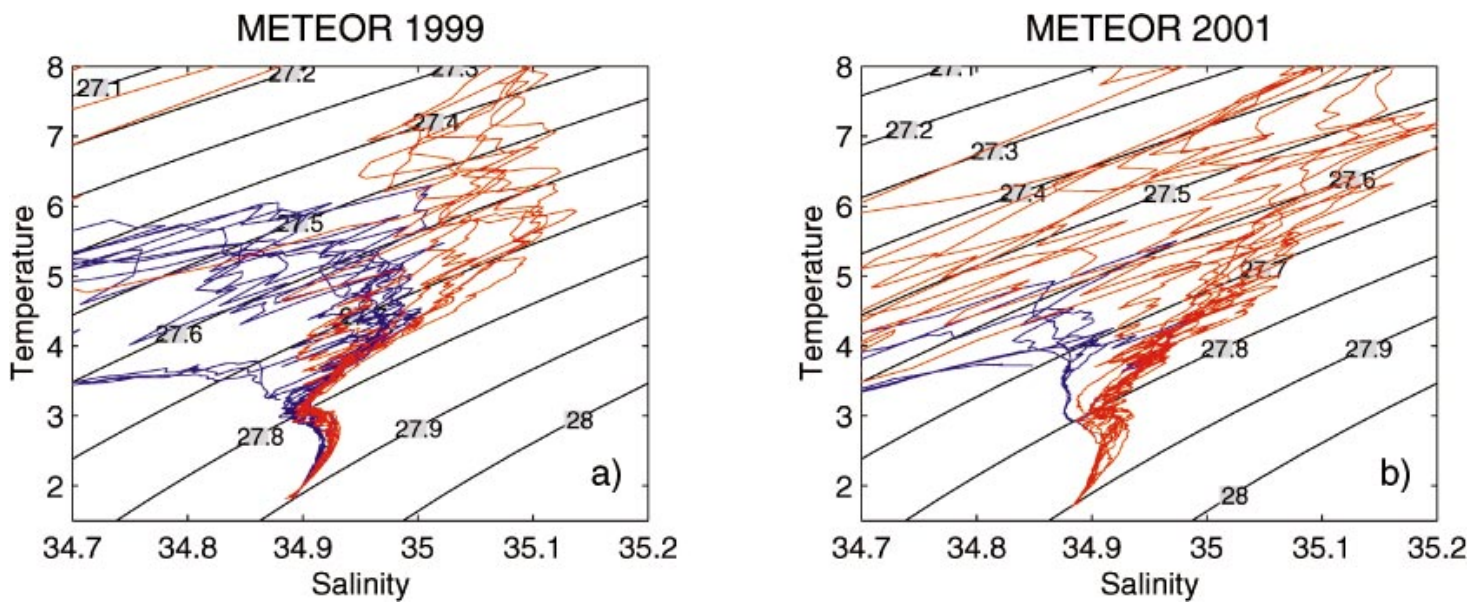

FIG. 15. Temperature-salinity diagrams of the deep water masses east of the Grand Banks from the (a) 1999 and (b) 2001 surveys, subdivided for the stations near the boundary (blue) and under the NAC (red).

for waters below the mean depth of the $\sigma_{\theta}=27.74 \mathrm{~kg}$ $\mathrm{m}^{-3}$ isopycnal and west of the mean zero isotach, Fig. 8 (subarea A, marked in Fig. 14). The southward DWBC transport in 1999 was $16.3 \mathrm{~Sv}$ for that subarea of the section. There was also $3.3 \mathrm{~Sv}$ of northward deep-water transport in the same portion of that section, yielding a net of 13.0 Sv of southward deep-water flow. For 2001 the southward deep-water transport was $9.9 \mathrm{~Sv}$ in subarea $\mathrm{A}$ but there was $5.8 \mathrm{~Sv}$ of northward flow at that time, resulting in only $4.1 \mathrm{~Sv}$ of net southward deepwater transport.

The transports of deep water determined from both shipboard current sections correspond reasonably well to the transports determined at the beginning and at the end of the moored time series (Fig. 13a). Overall, the two ship sections and their comparison with the moored time series confirm two main requirements for obtaining meaningful quantitative results of the circulation in this region: first, the need for direct current observations because of the lack of a proper geostrophic reference level and, second, the need for repeated measurements and temporal averaging because of vigorous shorterperiod variability.

\section{Watermass signatures and the distinction of the DWBC from the interior flow}

A major question regarding the transports reported in previous sections is whether the mean deep-water outflow of about $13 \mathrm{~Sv}$ below $\sigma_{\theta}=27.68 \mathrm{~kg} \mathrm{~m}^{-3}$ observed along the boundary (Fig. 8) is really an export of NADW, since immediately east of it a northward transport of more than double this amount is carried by the deep NAC (Fig. 8; Table 3). One would expect the deep water of the boundary current east of the Grand Banks to come out of the Labrador Sea, either as DSOW or GFZW cores along the boundary or as LSW outflow. However, float studies (Fischer and Schott 2002) showed that PALACE floats released in the DWBC near the exit of the Labrador Sea and drifting at 1500-m depth did not follow the boundary but moved eastward into the interior of the subpolar basin. Hence, the origin of the deep southward flow observed by the moored arrays east of the Grand Banks is not clear as of yet. Furthermore, for the deeper NAC transport in the GFZW and DSOW layers, there is no northern exit route; that water must return southward somewhere west of the Mid-Atlantic Ridge.

\section{a. Watermass distributions in the different NADW layers}

Here we explore whether a distinction by watermass signatures is possible between the southward boundary flow, to the west of station $1125 / \mathrm{K} 104$, and the northward return flow underneath the NAC (Figs. 2 and 8). The mean salinity section (Fig. 7) shows gradients from the near boundary to the NAC regime. These are largest in the upper layers but are also weakly existent at depth. This is apparent in the $T-S$ diagrams for the 1999 and 2001 surveys (Fig. 15), subdivided according to the current distributions observed (Fig. 14). For 1999, the division between the large southward core and the northward deep currents is near $47^{\circ} \mathrm{W}$ with lower salinities within the LSW, GFZW, and DSOW isopycnal layers for the southward flowing deep waters (blue) rather than farther offshore (red). In 2001 the near-boundary core is confined to the region west of $48.5^{\circ} \mathrm{W}$, and again the salinities in the region west of $48.5^{\circ} \mathrm{W}$ are reduced within the LSW density range in comparison with those observed farther offshore. For the southward flow at $47^{\circ}-48^{\circ} \mathrm{W}$, in between the two northward cores (Fig. 14b), the hydrographic signatures fall in between those from near the boundary and those from farther offshore.

A more general view is possible by examining the salinities on the core isopycnals of the different water 

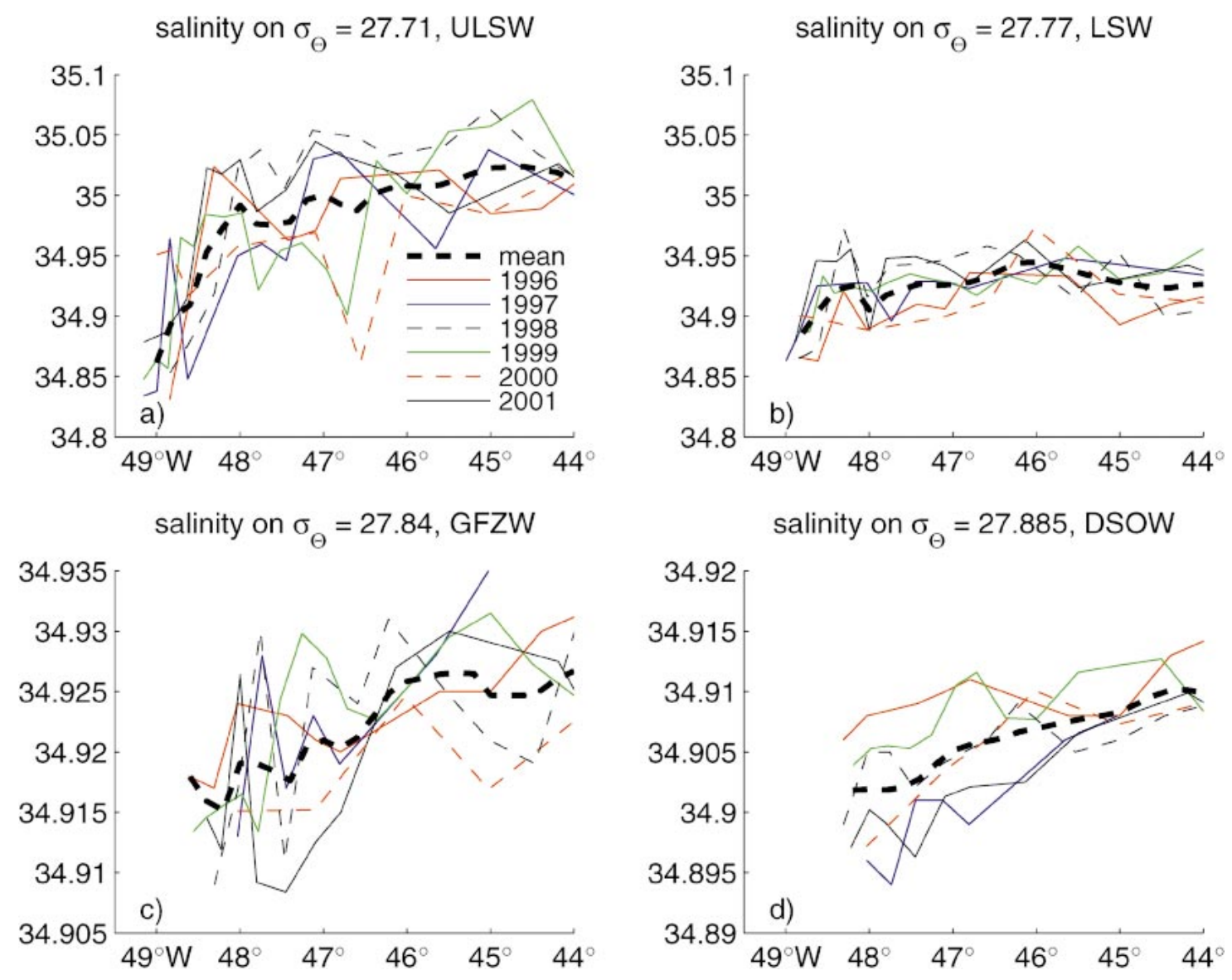

FIG. 16. Salinities from different surveys along the mooring section for core isopycnal surfaces: (a) $27.71 \mathrm{~kg} \mathrm{~m}^{-3}$ for upper Labrador Sea Water, (b) $27.77 \mathrm{~kg} \mathrm{~m}^{-3}$ for classical Labrador Sea Water, (c) $27.84 \mathrm{~kg} \mathrm{~m}^{-3}$ for Gibbs Fracture Zone Water, and (d) $27.885 \mathrm{~kg} \mathrm{~m}^{-3}$ for Denmark Strait Overflow Water.

masses in six sections taken during 1996-2001 (Fig. 16). The result shows a general increase from the southward outflow regime at the boundary to the northward return flow underneath the NAC. This increase is most pronounced for the upper LSW and LSW but still exists in the DSOW layer. The GFZW density range also shows low salinities near the western boundary, although the GFZW enters the western basin with high salinities through the Gibbs Fracture Zone (Fig. 1). However, since in the western subpolar basin low salinity water is located in the GFZW density range, the lower salinities are also observed near the shelf break off the Grand Banks.

For the WOCE section of 1997 and for the Kiel SFB 1999 and 2001 surveys, Freon (F-11) is also available on the core isopycnals of the different water masses (Fig. 17). The strongest gradients exist for the most recently ventilated upper LSW where a decrease of more than $1 \mathrm{pmol} \mathrm{kg}^{-1}$ is found normal to the boundary, but F-11 maxima along the boundary also occur for the older LSW and for the DSOW. For the unventilated GFZW (not shown) the concentrations are low and the Freon, while also showing a slight decrease from the boundary to the unventilated interior, does not appear to be a useful indicator for discriminating the DWBC from the interior.

\section{b. Transports in $\theta-S$ space}

Combining the mean mass distributions of the mean section (Fig. 7) with the mean current section (Fig. 8) allows calculation of the transport distribution in the $T$ $S$ space (Fig. 18). The distribution is shown for bins of $\Delta \theta=0.02^{\circ} \mathrm{C}, \Delta S=0.001$, with northward and southward flow contributions of each bin marked by colorcoded squares. In the LSW range, $\sigma_{\theta}=27.74-27.80$ $\mathrm{kg} \mathrm{m}^{-3}$, the northward flow is clearly distinguishable from the southward flow by its higher salinity. A similar result is also obtained for the GFZW range, $\sigma_{\theta}=27.80$ $27.88 \mathrm{~kg} \mathrm{~m}^{-3}$. In the DSOW range, however, for $\sigma_{\theta}>$ $27.88 \mathrm{~kg} \mathrm{~m}^{-3}$, the distinction is only clear in the upper part (Fig. 18); in the lower part, southward and northward contributions fall into the same $T-S$ domain.

In summary, the watermass signatures indicate that the southward flow directly along the boundary and the offshore northward flow are made up of different water 


\section{$\mathrm{F}-11 \mathrm{pmol} / \mathrm{kg}$ on $\sigma_{\Theta}=27.71, \mathrm{ULSW}$}

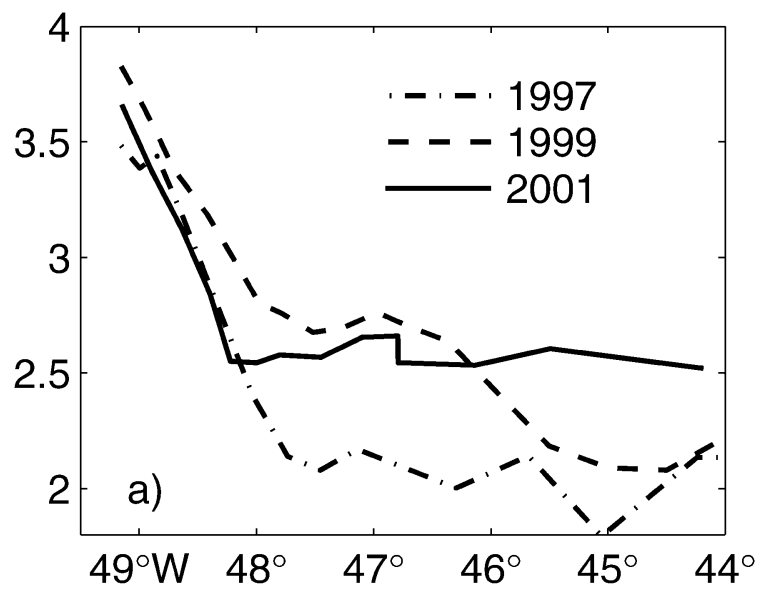

\section{$\mathrm{F}-11 \mathrm{pmol} / \mathrm{kg}$ on $\sigma_{\Theta}=27.885$, DSOW}

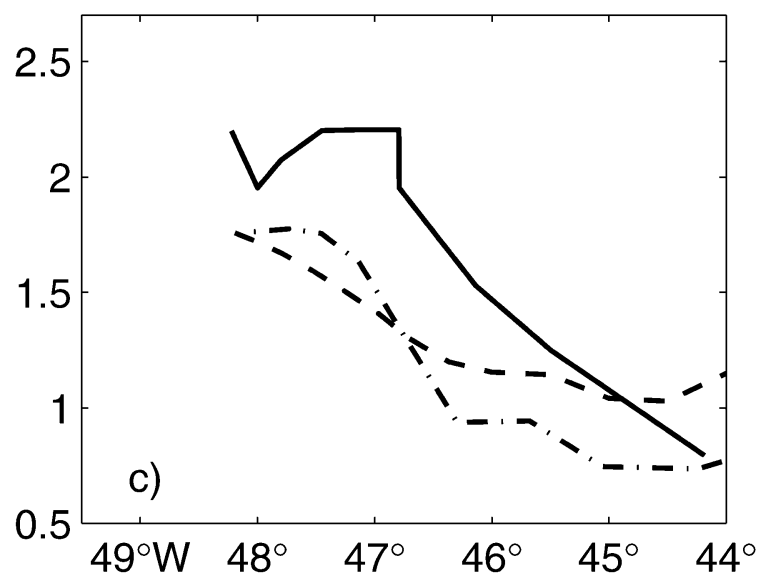

masses for the upper LSW, the LSW, the GFZW, and part of the DSOW, while for the lower portion of the DSOW, colder than $2^{\circ} \mathrm{C}$, the hydrography does not allow a distinction. Possibly, admixtures of Antarctic Bottom Water play a role there, slightly reducing the salinity of the deep NAC. There may also be biases involved due to the different times of sampling the hydrographic variability by the seven ship sections compared to the array deployment periods.

\section{Annual signal and variance distribution}

The eddy kinetic energies [EKEs; $\left.\frac{1}{2}\left(\left\langle u^{\prime 2}\right\rangle+\left\langle v^{\prime 2}\right\rangle\right)\right]$ of the moored current records reach maxima of about 800 $\mathrm{cm}^{2} \mathrm{~s}^{-2}$ in the upper NAC (Table 2; Fig. 19). The variance ellipses show a sharp difference between the NAC and the near-coastal regime, with the separation near $47^{\circ} \mathrm{W}$ (stations $1125 / \mathrm{K} 104$ ). The large ellipticity in the NAC domain indicates that meandering is an important part of the variance. Closer to the boundary, the current

\section{$\mathrm{F}-11 \mathrm{pmol} / \mathrm{kg}$ on $\sigma_{\Theta}=27.77, \mathrm{LSW}$}

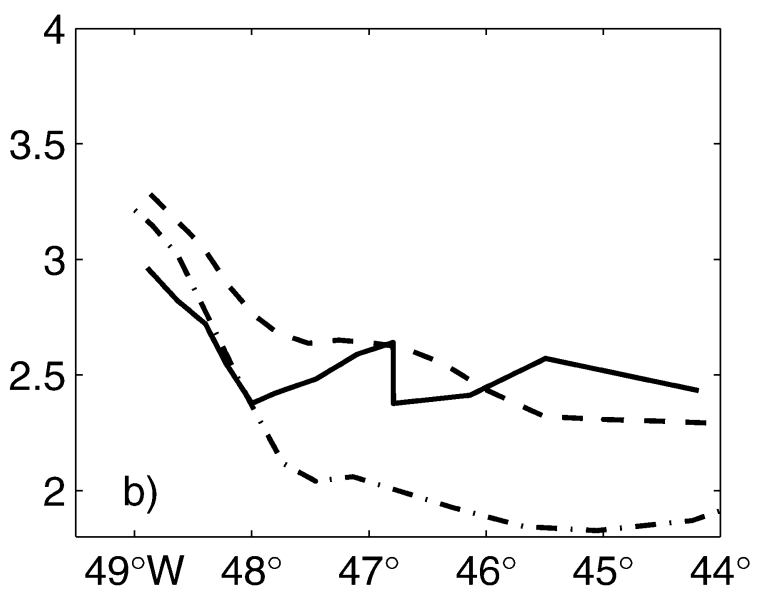

FIG. 17. As in Fig. 16 but for Freon concentrations (F-11) for Jun 1997, Jul 1999, and May 2001 and without the GFZW core layer (courtesy of M. Rhein). ellipses are more elongated and are oriented along the bathymetry.

The seasonal signal of the current variability was derived from the combined BIO and IfM moored array data and is weak overall (Fig. 20). The annual harmonic amplitude amounts to only $1-2 \mathrm{~cm} \mathrm{~s}^{-1}$ in the deep outflow part and rises to $5 \mathrm{~cm} \mathrm{~s}^{-1}$ at the $400-\mathrm{m}$ level, generally explaining only a small fraction $(<10 \%)$ of the variance. Though weak, the annual harmonics show a systematic pattern. Those from the DWBC are in antiphase with the deep NAC so that the maximum deep outflow occurs in December-February, while the deep NAC has its maximum northward flow during this part of the year. This suggests again that even the annual signal of the DWBC is influenced by the NAC meandering.

In any event, if a significant annual signal exists in the overturning or meridional heat transport between the Grand Banks and the European continent [as, e.g., suggested in the recent model results of Chassignet et al. 


\section{Volume transport census}

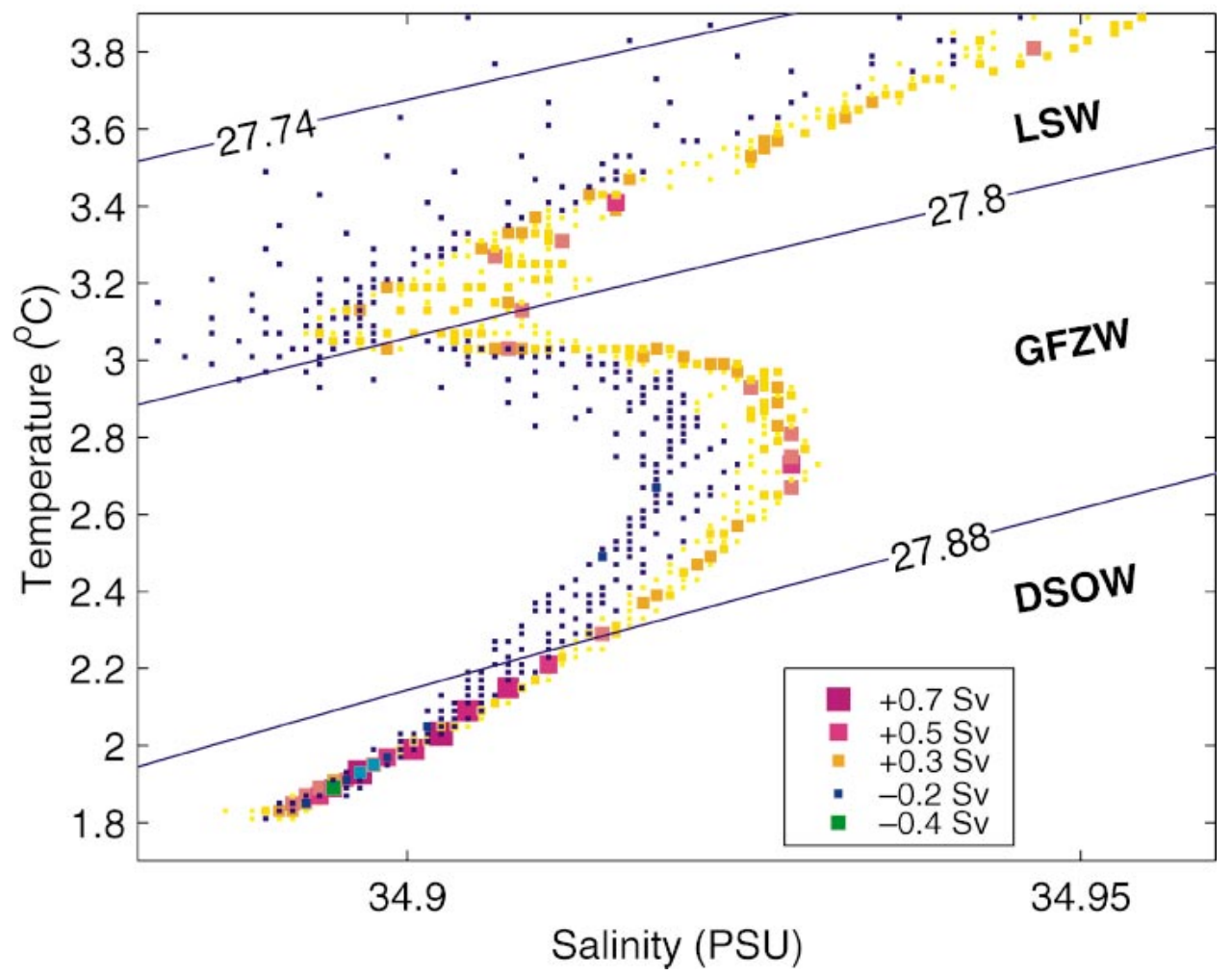

FIG. 18. Transport distribution in $\theta-S$ salinity space; isopycnals separating NADW layers are also marked.

(2003)], it would have to be caused elsewhere along the cross-Atlantic section (most likely by Ekman transport variability) and not along the western boundary.

From the time series of currents (Figs. 4 and 6) and transports (Figs. 9 and 11) in the different preceding sections one gets the impression that the variance is distributed in the period range between a few weeks and a few months. This is confirmed by current spectra, which show a broad maximum between about 2 weeks and 2 months. For the near-bottom records, the spectral shape is similar, but at an energy level that is almost an order of magnitude below that of the upper records. A wavelet analysis of the shallow and deep fluctuations did not indicate a seasonal cycle of the variance, suggesting that wind forcing, which varies drastically between winter and summer over the study region, is not influential.

\section{Summary and discussion}

We have analyzed here the currents from two moored arrays from east of the Grand Banks, both nearly two years long, combined with the results from a number of ship sections across the array site. The first array was deployed during 1993-95 by BIO, and the second one during 1999-2001 by IfM Kiel (Fig. 2). The main objective of this paper was to derive the mean deep-water transports from the combined coverage by both arrays and to compare the variability of currents and transports during the different deployment periods. The main results of our study are as follows.

1) A mean transport section was composed from all available observations, and the DWBC outflow below the isopycnal $\sigma_{\theta}=27.74 \mathrm{~kg} \mathrm{~m}^{-3}$ was determined to be $12.2 \mathrm{~Sv}$, with contributions of $3.3 \mathrm{~Sv}$ by the LSW, 4.3 Sv by the GFZW, and $4.6 \mathrm{~Sv}$ by the DSOW (Fig. 8; Table 3a).

2) There was, however, a deep northward flow of 51.2 $\mathrm{Sv}$ offshore from the DWBC, carried by the deepreaching NAC, resulting in a net northward deepwater transport of $39 \mathrm{~Sv}$ below the $27.74 \mathrm{~kg} \mathrm{~m}^{-3}$ isopycnal in the western portion of the Newfoundland Basin (Fig. 8; Table 3b). The watermass characteristics of the deep NAC were shown to differ from the western boundary outflow.

3) Transport time series were determined from both arrays for a DWBC subarea, defined as being below the mean $27.74 \mathrm{~kg} \mathrm{~m}^{-3}$ isopycnal and west of the mean zero isotach. The deployment-mean deep-water transports were found to be very similar, $11.3 \pm$ 1.1 Sv for 1993-95 and 11.2 $\pm 0.9 \mathrm{~Sv}$ for $1999-$ 2001, but this agreement might be coincidental because of the different and somewhat sparse DWBC coverage by the individual arrays. 


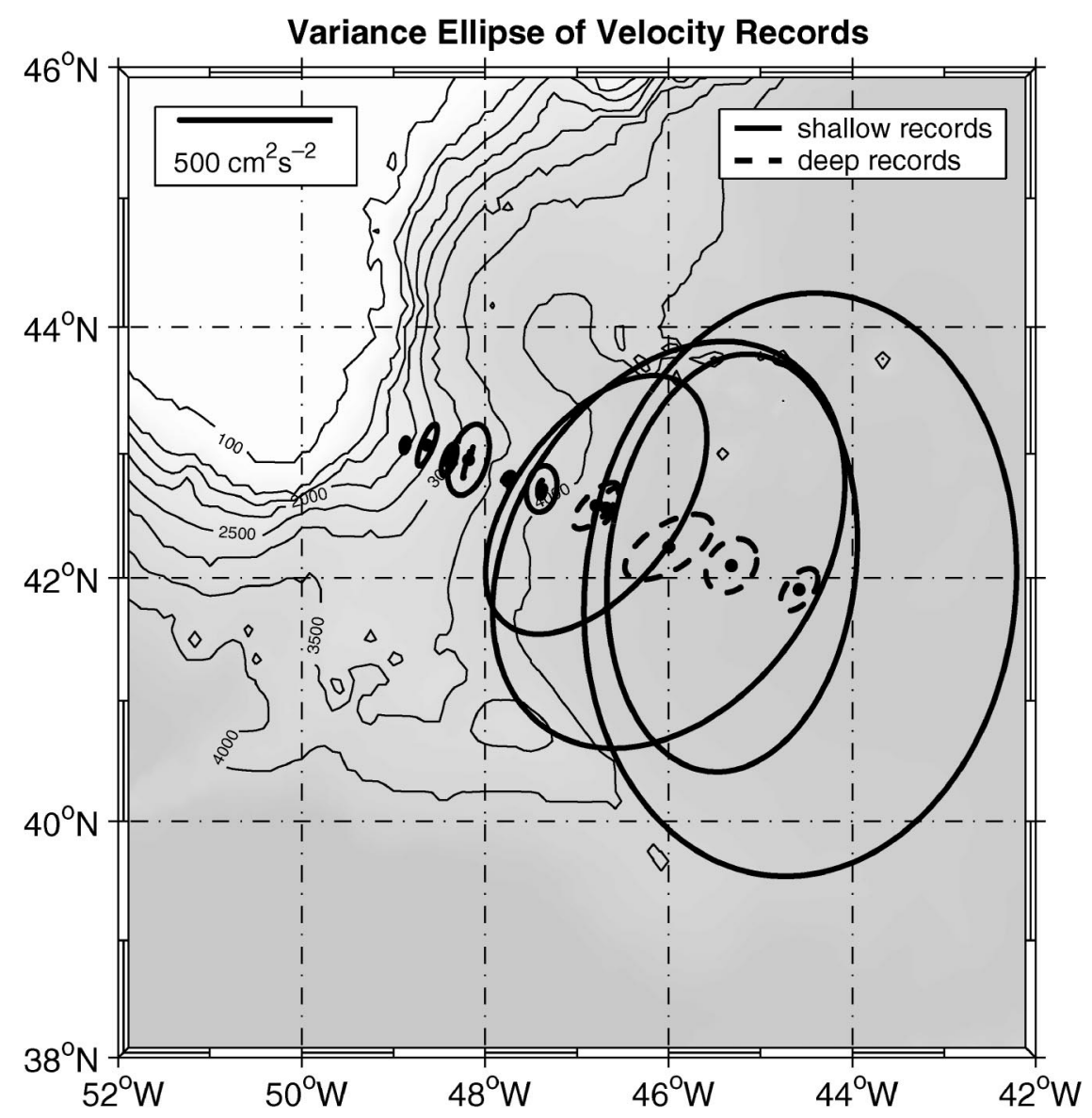

FIG. 19. Variance ellipses of the BIO and IfM moored records for upper-level near-400-m (solid) and near-bottom (dashed) instruments.

4) While the variance was concentrated in the weeksto-months time frame, there were also indications of interannual and longer-period changes in currents and transports (Fig. 13); however, it was concluded that the observed trends in the 1993-95 currents and deep-water transports were associated with NAC variability, not with NADW source variability.

\section{a. Comparison of the mean transports with other evidence at the larger scale}

\section{1) UPSTREAM TRANSPORTS AND CONTINUITY ALONG THE BOUNDARY}

Our mean southward NADW transport east of the Grand Banks of $12 \mathrm{~Sv}$ below $\sigma_{\theta}=27.74 \mathrm{~kg} \mathrm{~m}^{-3}$ can be compared with the similar section "upstream" (Fig. 1) at $53^{\circ} \mathrm{N}$ of FSD (their Fig. 12) at the southwestern exit of the Labrador Sea. The Labrador Current at $53^{\circ} \mathrm{N}$ has a much larger transport, of $26 \mathrm{~Sv}$ below $\sigma_{\theta}=27.74$ $\mathrm{kg} \mathrm{m}^{-3}$. A large boundary transport is to be expected in the Labrador Sea because of the cyclonic wind-driven circulation of that basin, which will also lead to a higher amount of DWBC transport. Associated with this wind- imposed flow field, there is northward recirculation east of the boundary current (Lavender et al. 2000; Spall and Pickart 2003), which is at least partially supplied out of the Labrador Current itself (Fischer and Schott 2002). From repeat ship sections, FSD estimated almost $8 \mathrm{~Sv}$ for this return flow, reducing the net southward export out of the Labrador Sea to about $18 \mathrm{~Sv}$.

As indicated by trajectories of profiling floats released at $1500 \mathrm{~m}$ in the DWBC of the southwestern Labrador Sea (Fischer and Schott 2002) or elsewhere in the Labrador Sea (Lavender et al. 2000) and by tracer distributions (Freon) from the LSW core layer (Rhein et al. 2002), there does not appear to be continuity of the upper part of the DWBC from the exit of the Labrador Sea to east of the Grand Banks. On the other hand, at each location studied with moorings or ship sections (FSD; our Fig. 8) there is always a concentrated southward boundary current in the LSW density range. An update of the Fischer and Schott (2002) trajectories shows the main spreading paths of the PALACE floats released in 1997-99 near the Labrador Sea exit, complemented by Autonomous Profiling Explorer (APEX) releases in 2001 (Fig. 21).

None of the floats released in the southern Labrador 


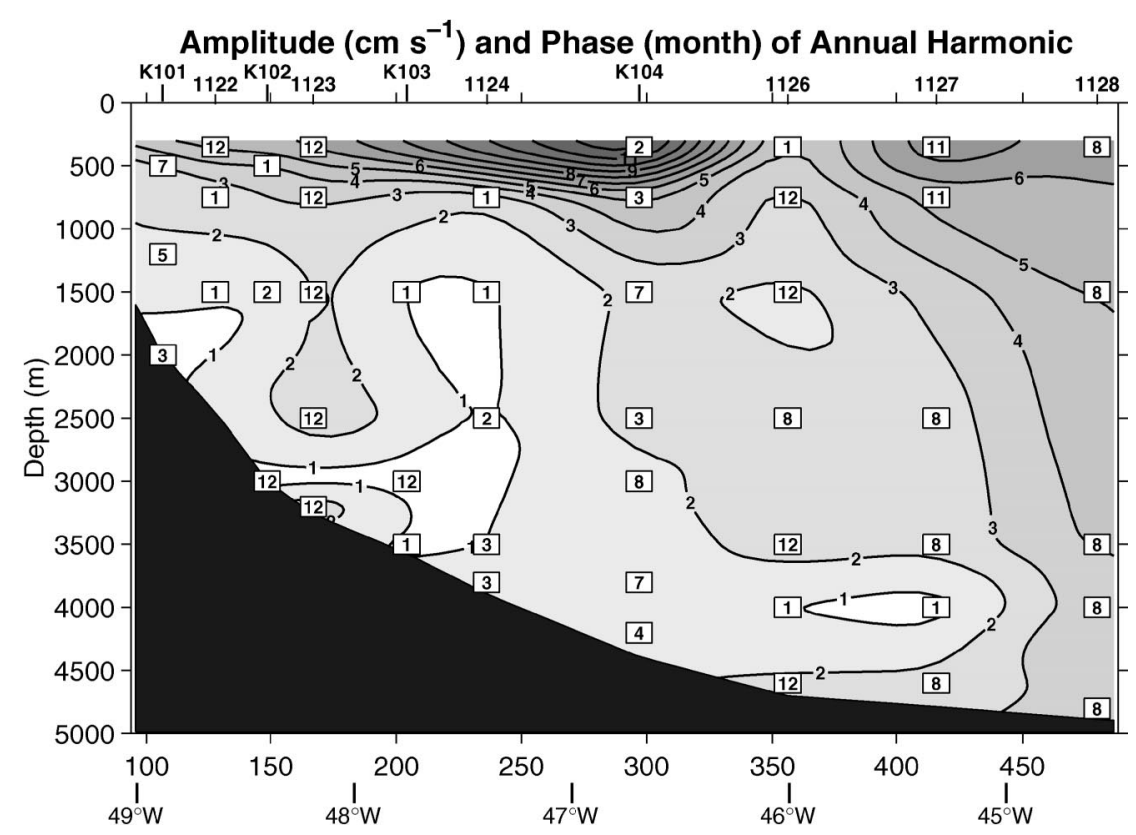

FIG. 20. Annual harmonic amplitude (contours) and phase of maximum southward flow in months (numbers) of current fluctuations normal to mooring line, determined from combined $\mathrm{BIO}$ and IfM array data.

Sea managed to stay in the DWBC all the way to the Grand Banks. Of course, floats are sensitive to eddy motion and get easily detrained out of the mean boundary flow. Another possible conclusion is that this apparent discontinuity of the DWBC may have to do with the lack of deep Labrador Sea convection in the most recent years (Lazier et al. 2002; SDSR). Besides the main propagation float path along the northern flank of the NAC and secondary spreading into the Irminger Sea, as already discussed by Fischer and Schott (2002), there is in the recently extended trajectories also evidence for southward spreading of LSW layer waters in the vicinity of the Mid-Atlantic Ridge (MAR; Fig. 21), and we accounted for it in our schematic diagram by inserting southward LSW tracks (white, Fig. 1) in the interior of the basin. However, a float released directly at the moored array location east of the Grand Banks was swept southwestward toward Cape Hatteras (Fig. 21), suggesting that deep outflow along the western boundary existed despite the lack of boundary current continuity from the Labrador Sea to the exit of the subpolar western basin. This occurred even at a period of very weak DWBC flow during the time of the float release (Figs. 14b,d).

\section{2) Deep Recirculation And MOC Along THE $48^{\circ} \mathrm{N}$ SECTION}

The large mean northward deep-water flow, $51 \mathrm{~Sv}$ below $\sigma_{\theta}=27.74 \mathrm{~kg} \mathrm{~m}^{-3}$ (Fig. 8), that was associated with the deep NAC is a somewhat surprising result. The bathymetry would only allow net northward deep flow for the LSW because that can pass over the MAR in the north. For the DSOW layer below $\sigma_{\theta}=28.88 \mathrm{~kg}$ $\mathrm{m}^{-3}$, there was a net northward flow of $6.8 \mathrm{~Sv}$ that must return southward somewhere in the basin; for the GFZW layer, there was a net northward flow of $12.1 \mathrm{~Sv}$. Assuming mean westward transports through the Gibbs Fracture Zone, this transport must also return southward to the west of the MAR. Then there must be a southward flow somewhere east of the BIO array longitude of at least the 18.9 Sv of the two deepest layers plus their presumed deep export to the Tropics-an additional amount of about $10 \mathrm{~Sv}$ - for a total of nearly $30 \mathrm{~Sv}$.

We inspected watermass signatures obtained by hydrographic and tracer observations to determine whether the southward DWBC flow could be distinguished from the northward deep NAC. The result was that in salinities (Figs. 16 and 18) and Freon concentrations (Fig. 17) the western boundary outflow regime differed markedly from the deep NAC recirculation regime farther offshore. We conclude from the watermass signatures that the deep NAC is not a recirculation of the western boundary outflow, at least not immediately and without notable watermass modification.

There have been various pieces of evidence presented such as geostrophy sections (Mann 1967; Schmitz and McCartney 1993) and drifter or float tracks (Käse and Krauss 1996; Carr and Rossby 2001; Reverdin et al. 2003) suggesting the existence of one or more semipermanent eddies east of the Grand Banks. The most prominent of these, the "Mann Eddy," is presumably located at the outer edge of the moored section for which Meinen (2001), based on the earlier evidence, quoted a 


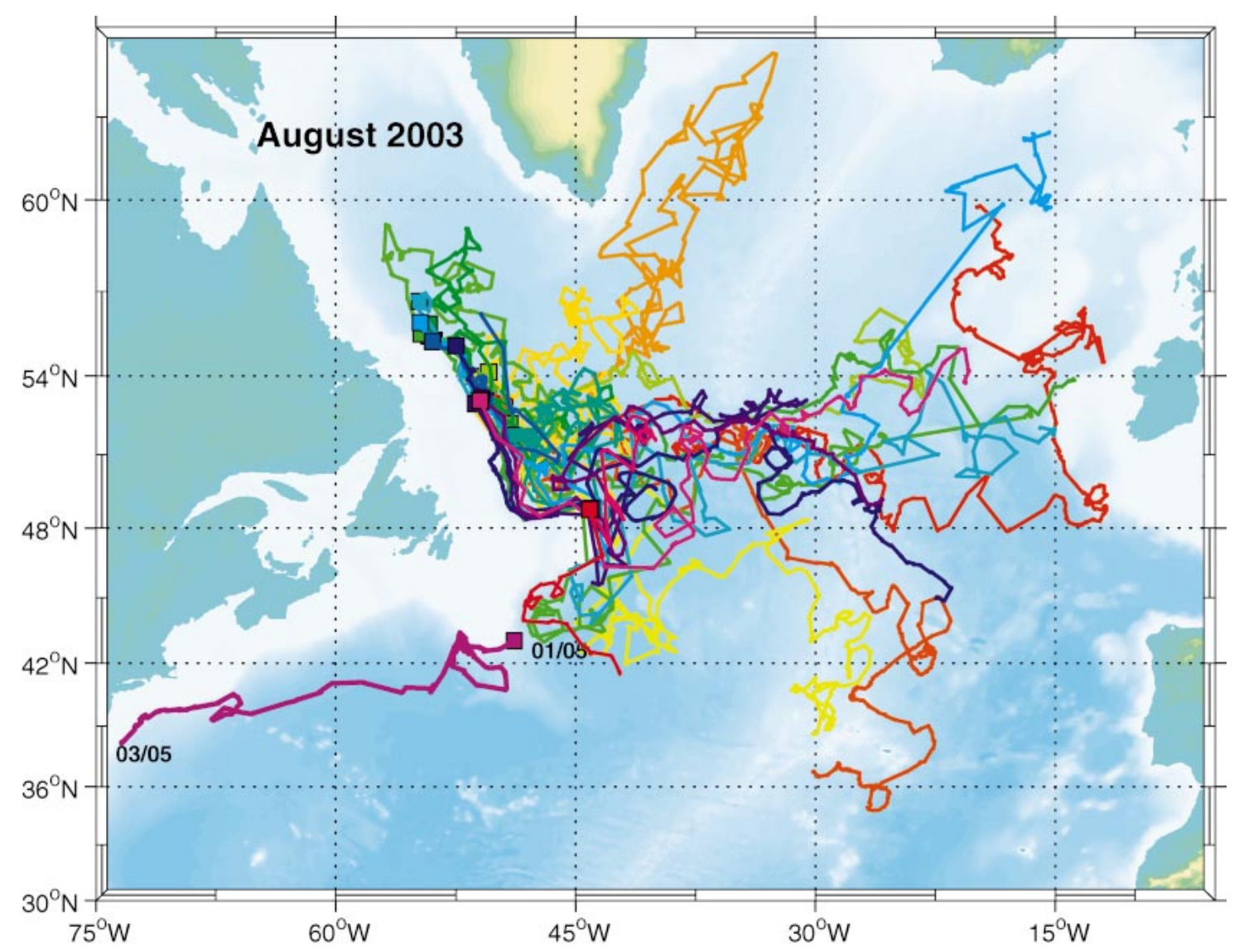

FIg. 21. Trajectories (as of Aug 2003) of PALACE-APEX floats drifting at $1500 \mathrm{~m}$, deployed during 1997-2001 by IfM Kiel (deployment locations marked by squares); start and end dates (yy/mm) of float released in May 2001 at the array site are included.

transport estimate of $55 \mathrm{~Sv}$. As mentioned in previous sections, there seems to be some kind of a regime shift during the last several months of the BIO observations, manifested by deep-reaching southward flow at the offshore side of the BIO array (Fig. 9). What we do not see is an increased NAC at the same time as an increase of southward transport east of the NAC (Fig. 11), that is, evidence for an addition of a Mann Eddy to the transport of the preexisting NAC, and the evidence from the moored station data for its existence remains weak, from our perspective.

Recent inverse calculations have yielded an overturning circulation of $14 \pm 2 \mathrm{~Sv}$ (Ganachaud and Wunsch 2000) and $14.1 \pm 1.2 \mathrm{~Sv}$ (Lumpkin and Speer 2003) across the WOCE A2/AR19 line, nominally at $48^{\circ} \mathrm{N}$, which reaches the western boundary near $43^{\circ} \mathrm{N}$. The latter authors determine a much larger DWBC then our observations of $29 \pm 12 \mathrm{~Sv}$ with an interior northward recirculation of $14 \pm 12 \mathrm{~Sv}$. They caution, however (R. Lumpkin 2003, personal communication), that their inverse calculation might be insensitive to alternating near-barotropic currents as determined by us that are not zonally distinguishable by sufficiently large hydrographic differences. Lumpkin and Speer are there- fore much more confident in the net layer transports than in zonal recirculation features along the $48^{\circ} \mathrm{N}$ section. The net layer exports of the Lumpkin and Speer calculation compare well with our DWBC (Fig. 8): they obtain $1.0 \pm 0.8 \mathrm{~Sv}$ versus our $0.7 \mathrm{~Sv}$ for upper LSW, $4.0 \pm 2.0$ versus our $3.3 \mathrm{~Sv}$ for LSW, $4.8 \pm 1.6 \mathrm{~Sv}$ versus our $4.3 \mathrm{~Sv}$ for $\mathrm{GFZW}$, and $5.0 \pm 1.6 \mathrm{~Sv}$ versus our 4.6 Sv for DSOW [R. Lumpkin (2003, personal communication); cf. our Table 3a].

\section{3) Model Results on $48^{\circ} \mathrm{N}$ mean overturning}

A number of model simulations are presently studied concerning the outflow structure across the " $48^{\circ} \mathrm{N}$ line," which is along a zonal line at $43^{\circ} \mathrm{N}$, and we only summarize some preliminary results for comparison with our observations. In the recent simulation of Chassignet et al. (2003, their Fig. 13) with the low-resolution $\left(1^{\circ}\right)$ version of the Miami Isopycnic Model (MICOM), the meridional transports for layers below potential density $27.72 \mathrm{~kg} \mathrm{~m}^{-3}$ show the DWBC along the western boundary with the deep-reaching NAC offshore and then southward currents farther to the east. East of these three confined flows very little meridional exchange occurs. 
The MICOM result that the main exchange with the subtropical basin occurs in the western half of the western basin does not significantly change if higher resolution $\left(1 / 12^{\circ}\right)$ or different forcing fields are applied (L. Smith and Z. Garraffo 2003, personal communications).

In contrast to these results, the IfM Kiel Family of Linked Atlantic Model Experiments (FLAME) model (C. Boening 2003, personal communication) at $1 / 3^{\circ}$ resolution yields only a small outflow fraction in the layers below potential density $27.74 \mathrm{~kg} \mathrm{~m}^{-3}$ east of the Grand Banks, but then there is northward return flow farther east along $43^{\circ} \mathrm{N}$, with the net result that there is basically no net NADW outflow in the basin west of about $40^{\circ} \mathrm{W}$. Only eastward from $40^{\circ} \mathrm{W}$ does that model yield several bands of southward flow. In a model version with the resolution increased to $1 / 12^{\circ}$, the pattern is similar: more deep reversing meridional currents in the western basin, but again no net deep southward flow between the western boundary and about $40^{\circ} \mathrm{W}$. However, Lagrangian particle studies showed a significant difference between both models: while at the LSW level the DWBC in the $1 / 3^{\circ}$ version recirculated northward at the Tail of the (model) Grand Banks, the LSW flow continued southward along the western boundary toward Cape Hatteras in the $1 / 12^{\circ}$ version, much in agreement with our APEX drifter released at the array site (Fig. 21).

The effects of data assimilation are also interesting for the interpretation of our work: Eden et al. (2004) have compared two kinds of model output from along our moored section. First, for a prognostic case corresponding essentially to the FLAME model, they also obtain the dominant LSW outflow in the eastern basin. However, when they force the momentum equations in the model to approximate climatological geostrophy, much of the deep mean outflow is forced to the western boundary. A similar result was obtained by Stammer et al. (2002). Comparison of the Estimating the Circulation and Climate of the Ocean (ECCO) assimilation run with the prognostic run showed that the assimilation forced a cyclonic deep circulation east of the Grand Banks that enhanced the DWBC with the result that much of the deep-water export across $43^{\circ} \mathrm{N}$ was concentrated along the western boundary as well.

\section{b. Variability of deep-water formation and MOC}

One finding of our study is the similarity of the current and transport means, obtained from about 22month-long time series six years apart (Fig. 13; Table 4). The deployment-mean currents could be directly compared for the one station, 1125, of the 1993-95 array that was repeated in 1999-2001 by station K104 (Fig. 3 ) and the mean vertical profiles of the alongshore components agree closely (Table 2). For the transports determined separately from both arrays, the close agreement may be coincidental because of the sparse and different sampling of the DWBC by the individual arrays.
Yet, the similarity among both sets of observations is interesting given the large difference in the convection situation of both observational periods. While the BIO array observations of 1993-95 were obtained shortly after the period of maximum Labrador Sea convection, the IfM Kiel array measurements of 1999-2001 were taken during one of the weakest convection periods ever observed in the Labrador Sea (Lazier et al. 2002; SDSR). On the other hand, the 1993-95 southward deep-water transport time series (Fig. 13b) showed a significant decreasing trend of $5.9 \mathrm{~Sv} \mathrm{yr}^{-1}$. However, this trend was not confined to the LSW or deeper NADW layers; it was related to much stronger current trends in the entire NAC system (Fig. 12c).

The LSW production anomalies of the past decades have been traced through the western Atlantic. Curry et al. (1998) found a time lag of 6 yr between LSW thickness anomalies in the central Labrador Sea and middepth temperatures near Bermuda, Molinari et al. (1998) estimated a time lag of about $10 \mathrm{yr}$ for LSW anomalies to arrive east of the Bahamas, and Stramma and Rhein (2001) estimated 13-17 years for LSW anomalies to arrive at the equator. What is unclear is what kind of transport anomalies are associated with these LSW thickness anomalies; are they just passively swept along or are they affecting the DWBC transports? What magnitude of interannual variations should be expected?

A possible answer can be derived from the analysis of the WOCE line A2/AR19 from the Grand Banks to the English Channel, nominally the $48^{\circ} \mathrm{N}$ section (and meeting the western boundary near $43^{\circ} \mathrm{N}$ ), which has been observed seven times since 1957 (Koltermann et al. 1999). Speer et al. (2003, manuscript submitted to J. Mar. Res.) analyzed five sections taken almost annually during the WOCE period (1993-98 and 2000) with the box inverse model used previously by Lumpkin and Speer (2003) for estimating the mean overturning circulation. The northern (at the overflow sills) and southern (at $11^{\circ} \mathrm{S}$ ) boundary conditions were held constant while National Centers for Environmental Prediction (NCEP) heat and freshwater fluxes were applied in the outcrop regions. Diapycnal mixing was either held constant or allowed to also adjust within bounds.

The overturning transports for the constant mixing case varied only slightly (where it has to be explored how much that was due to the southern and northern constant boundary conditions) with a minimum of 12 $\mathrm{Sv}$ (1996) and a maximum of $15 \mathrm{~Sv}$ (1997); for the adjustable mixing case the MOC variation was even less. However, the layer transports and recirculations showed much more variability than the total MOC transports. The DWBC varied from $13 \mathrm{~Sv}$ (2000) to $26 \mathrm{~Sv}$ (1998) and, correspondingly, the northward recirculation east of the DWBC was largest in 1998, at about $18 \mathrm{~Sv}$, and smallest in 2000, at about $7 \mathrm{~Sv}$ (R. Lumpkin 2003, personal communication).

A number of model studies have analyzed the role of LSW production in Atlantic MOC variability. Mauritzen 
and Häkkinen (1999) found an increase of the MOC with increased LSW production, but it was less than expected from the dense water formation change. Eden and Willebrand (2001) concluded that interannual NCEP air-sea flux anomalies over the Labrador Sea could cause an interannual MOC variability of not more than $O(1 \mathrm{~Sv})$. More general, a recent intercomparison study among four different models yielded the result that the interannual MOC variability of the individual models in response to NCEP flux variability showed striking similarities despite the differences of resolution and physics of the individual models, with rms amplitudes of $<1 \mathrm{~Sv}$ (Beismann et al. 2002).

\section{c. Concluding remarks}

The IfM Kiel array observations in the Labrador Sea and east of the Grand Banks are continuing until 2005 in order to obtain longer time series of deep-water transports and watermass changes along the western boundary. The continuation of our analysis of the observed variability will focus on isolating that fraction of the deep variability east of the Grand Banks that is not masked by the NAC meandering and linking it to current and watermass anomalies at observation sites "upstream" in the Labrador Sea. Furthermore, in response to the model results summarized above, the array is extended eastward by two geostrophy moorings, using moored profiling CTDs (including acoustic current meters) in the interior of the basin, to obtain time series of transport fluctuations to the east of the basin covered by the previous station network as described in this presentation. While these observations continue, we look forward to seeing a convergence of model results regarding both the longitudinal distribution of the deepwater outflow across $43^{\circ} \mathrm{N}$ and the structure and mechanisms of the interannual to decadal MOC variations obtained in decadal model runs.

Acknowledgments. We thank the captain and crew of $\mathrm{R} / \mathrm{V}$ Meteor as well as Uwe Papenburg and Mario Mueller of IfM Kiel for their help in deploying and retrieving the moored array during cruises M45/3 and M50/1. We further thank Monika Rhein (University of Bremen) for letting us use unpublished Freon data (Fig. 17) from both cruises. Eric Chassignet, Zulema Garraffo, and Linda Smith (RSMAS, University of Miami) carried out transport calculations across $43^{\circ} \mathrm{N}$ for several of their MICOM model versions for intercomparison studies. Helpful discussions with Chris Meinen (NOAA/ AOML) and recalculations he did for us from his earlier work on the WOCE BIO array are also acknowledged, as well as evaluations of the box inverse model by Rick Lumpkin (NOAA/AOML, Miami). We further thank Allyn Clarke (BIO), Peter Brandt (IfM Kiel), Jonathan Lilly (University of Washington), and an anonymous reviewer for constructive comments that helped to improve the manuscript. This work was supported by the
German Research Foundation (DFG) as part of the Sonderforschungsbereich SFB 460 project: Dynamics of the Thermohaline Circulation Variability. Part of the work for this paper was performed while the first author (FS) was a visiting scientist at CIMAS/AOML, Miami, during spring 2003, and he acknowledges their hospitality.

\section{REFERENCES}

Beismann, J. O., C. W. Boening, and D. Stammer, 2002: Inter-annual to decadal variability of the meridional overturning circulation of the Atlantic: A comparison of the responses to atmospheric fluctuations in three ocean models. CLIVAR Exchanges 25, Vol. 7, No. 3/4, International CLIVAR Project Office, Southampton, United Kingdom, 34-46. [Available online at www.clivar.org/ publications/exchanges/ex25/ex25.pdf.]

Carr, M.-E., and T. Rossby, 2001: Pathways of the North Atlantic Current from surface drifters and subsurface floats. J. Geophys. Res., 106 (C3), 4405-4419.

Chassignet, E. P., L. T. Smith, G. R. Halliwell, and R. Bleck, 2003: North Atlantic simulations with the Hybrid Coordinate Ocean Model (HYCOM): Impact of the vertical coordinate choice in reference pressure and thermobaricity. J. Phys. Oceanogr., 33, 2504-2526.

Clarke, R. A., R. M. Hendry, and I. Yashayev, 1998: A western boundary current meter array in the North Atlantic near $42^{\circ} \mathrm{N}$. WOCE Newsletter, No. 33, WOCE International Project Office, Southampton, United Kingdom, 33-34.

Curry, R., M. S. McCartney, and T. M. Joyce, 1998: Oceanic transport of subpolar climate signals to mid-depth subtropical waters. $\mathrm{Na}$ ture, 391, 575-577.

Eden, C., and J. Willebrand, 2001: Mechanism of interannual to decadal variability of the North Atlantic circulation. J. Climate, 14, 2266-2280.

—, R. J. Greatbatch, and C. W. Böning, 2004: Adiabatically correcting an eddy-permitting model using large-scale hydrographic data: Application to the Gulf Stream and the North Atlantic Current. J. Phys. Oceanogr., 34, 701-719.

Fischer, J., and F. Schott, 2002: Labrador Sea Water tracked by profiling floats-From the boundary current into the open North Atlantic. J. Phys. Oceanogr., 32, 573-584.

_- P. Brandt, M. Dengler, M. Müller, and D. Symonds, 2003: Surveying the upper ocean with the Ocean Surveyor-A new phased array Doppler current profiler. J. Atmos. Oceanic Technol., 20, 742-751.

, F. Schott, and M. Dengler, 2004: Boundary circulation at the exit of the Labrador Sea. J. Phys. Oceanogr., in press.

Fratantoni, D. M., 2001: North Atlantic surface circulation during the 1990s observed with satellite-tracked drifters. J. Geophys. Res., 106 (C10), 22 067-22 093.

Ganachaud, A., and C. Wunsch, 2000: Improved estimates of global ocean circulation, heat transport and mixing from hydrographic data. Nature, 408, 453-457.

Käse, R. H., and W. Krauss, 1996: The Gulf Stream, the North Atlantic Current, and the origin of the Azores Current. The Warmwatersphere of the North Atlantic Ocean, W. Krauß, Ed., Gebrueder Bornträger, 291-337.

Koltermann, K. P., A. V. Sokov, V. P. Terechtchenkov, S. A. Dobroliubov, K. Lorbacher, and A. Sy, 1999: Decadal changes in the thermohaline circulation of the North Atlantic. Deep-Sea Res., 46A, 109-138.

Krauss, W., 1986: The North Atlantic Current. J. Geophys. Res., 91 (C4), 5061-5074.

Lavender, K. L., R. E. Davis, and W. B. Owens, 2000: Mid-depth recirculation observed in the interior Labrador and Irminger Seas by direct velocity measurements. Nature, 407, 66-69.

Lazier, J., R. Hendry, A. Clarke, I. Yashayev, and P. Rhines, 2002: 
Convection and restratification in the Labrador Sea, 1990-2000. Deep-Sea Res., 49A, 1819-1835.

Lumpkin, R., and K. Speer, 2003: Large-scale vertical and horizontal circulation in the North Atlantic Ocean. J. Phys. Oceanogr., 33, 1902-1920.

Mann, C. R., 1967: The termination of the Gulf Stream and the beginning of the North Atlantic Current. Deep-Sea Res., 14, 337359.

Mauritzen, C., and S. Häkkinen, 1999: On the relationship between dense water formation and the "meridional overturning cell" in the North Atlantic Ocean. Deep-Sea Res., 46A, 877-894.

Meinen, C. S., 2001: Structure of the North Atlantic Current in stream-coordinates and the circulation in the Newfoundland $\mathrm{Ba}$ sin. Deep-Sea Res., 48A, 1553-1580.

- , and D. R. Watts, 2000: Vertical structure and transport on a transect across the North Atlantic Current near $42^{\circ} \mathrm{N}$ : Time series and mean. J. Geophys. Res., 105 (C9), 21 869-21 891.

Molinari, R. L., R. A. Fine, W. D. Wilson, R. G. Curry, J. Abell, and M. S. McCartney, 1998: The arrival of recently formed Labrador Sea Water in the Deep Western Boundary Current at $26.5^{\circ} \mathrm{N}$. Geophys. Res. Lett., 25, 2249-2252.

Petrie, B., and J. Buckley, 1996: Volume and freshwater transport of the Labrador Current in Flemish Pass. J. Geophys. Res., 101 (C12), 28 335-28 342.

Reverdin, G., P. P. Niiler, and H. Valdimarsson, 2003: North Atlantic surface currents. J. Geophys. Res., 108, 3002, doi:10.1029/ 2001JC001020.
Rhein, M., and Coauthors, 2002: Labrador Sea Water: Pathways, CFC inventory, and formation rates. J. Phys. Oceanogr., 32, 648665.

Rossby, T., 1996: The North Atlantic Current and surrounding waters: At the crossroads. Rev. Geophys., 34, 463-481.

Schmitz, W. J., Jr., and M. S. McCartney, 1993: On the North Atlantic circulation. Rev. Geophys., 31, 29-49.

Sciremammano, F., 1979: A suggestion for the presentation of correlations and their significance levels. J. Phys. Oceanogr., 9, 1273-1276.

Spall, M. A., and R. S. Pickart, 2003: Wind-driven recirculations and exchanges in the Irminger and Labrador Seas. J. Phys. Oceanogr., 33, 1829-1845.

Stammer, D., and Coauthors, 2002: The global ocean circulation during 1992-1997, estimated from ocean observations and a general circulation model. J. Geophys. Res., 107, 3118, doi:10.1029/ 2001JC000888.

Stramma, L., and M. Rhein, 2001: Variability in the Deep Western Boundary Current in the equatorial Atlantic at $44^{\circ} \mathrm{W}$. Geophys. Res. Lett., 28, 1623-1626.

Visbeck, M., 2002: Deep velocity profiling using lowered acoustic Doppler current profilers: Bottom track and inverse solutions. $J$. Atmos. Oceanic Technol., 19, 794-807.

Worthington, L. V., 1976: On the North Atlantic Circulation. Johns Hopkins Oceanographic Studies Series, No. 6, The Hopkins University Press, $110 \mathrm{pp}$. 